\title{
Molecular evidence resolving the confusion of two species of Spilopteron (Hymenoptera: Ichneumonidae) caused by marked geographical colour variation
}

\author{
Masato ITO $^{1}$, Kyohei WATANABE ${ }^{2}$ and KaORU MAETO ${ }^{1}$ \\ ${ }^{1}$ Laboratory of Insect Biodiversity and Ecosystem Science, Graduate School of Agricultural Science, Kobe University, \\ Rokkodaicho 1-1, Nada, Kobe, Hyogo 657-8501, Japan; e-mails: fixsenia@hotmail.co.jp (MI); maeto@kobe-u.ac.jp (KM) \\ ${ }^{2}$ Kanagawa Prefectural Museum of Natural History, Iryuda 499, Odawara, Kanagawa 250-0031, Japan; \\ e-mail: himebati-love@hotmail.co.jp
}

Key words. Hymenoptera, Ichneumonidae, Spilopteron, systematics, Japan, latitudinal gradient, mtCOI, nuclear 28S, parasitoid, thermal melanism

\begin{abstract}
The delimitation of two ichneumonid species, Spilopteron apicale (Matsumura) and S. tosaense (Uchida), was investigated using DNA sequences of the mitochondrial COI and nuclear 28S rRNA genes, as well as adult morphology. The two species have long been confused and were until recently speculated to be the same species with continuous colour variation. Our molecular and morphological studies reveal that there are two distinct species: a dark species confined to northern or high latitude localities (S. apicale) and a widely distributed species with a marked geographical gradient in body colour (S. tosaense) across the Japanese Archipelago. In the latter species, female body colour became significantly darker with latitude and altitude. A lectotype of Chorischizus apicalis Matsumura, 1912 is designated.
\end{abstract}

\section{INTRODUCTION}

The classification of parasitoid wasps has long been based on morphological characteristics such as body proportions, surface structures, wing venation, and hair distribution. The use of body colour has also been common in identification, because of the ease of using this characteristic and the fact that it is genuinely reliable in some instances (Quicke et al., 2006). However, there is often large intraspecific variation in body colour due to genetic and environmental factors (Abe et al., 2013). Because of recent developments in molecular taxonomy, mitochondrial and nuclear DNA sequences have increasingly been used for the species-level classification of parasitoid wasps (e.g., Quicke et al., 2006; Rugman-Jones et al., 2009; Stigenberg et al., 2011). Accurate biological classification using both morphological and molecular data is sometimes possible, but many parasitoid groups are still far from seeing the benefit of molecular taxonomy.

Spilopteron Townes is a medium-sized genus of the ichneumonid subfamily Acaenitinae. It contains 30 species worldwide, eleven of which are known from the Palaearctic region (Yu et al., 2012). They are all large species, $10.0-20.0 \mathrm{~mm}$ in body length, and primarily parasitic on cerambycid larvae (Kusigemati, 1981; Yu et al., 2012). Since Shaw \& Wahl (1989) reported that a related species, Acaenitus dubitator (Panzer, 1800), is a koinobiont endoparasitoid of beetle larvae, it is possible that Spilopteron utilizes the same strategy of parasitism.

In Japan, five species of Spilopteron, S. apicale (Matsumura, 1912) [=S. apicalis], S. tosaense (Uchida, 1934) [= S. tosensis], S. pyrrhonae Kusigemati, 1981, S. mu- cronatum Lee, 2008, and S. luteum (Uchida, 1930), have been recorded (Kusigemati, 1981; Ito et al., 2012; Yu et al., 2012). According to Kusigemati (1981), his dark-coloured species "S. apicalis" from the northern islands of Japan (Hokkaido and Honshu) was clearly distinguished from his light-coloured species "S. tosensis" from the southern islands (Shikoku, Kyushu, and Yakushima Is.) (cf. Fig. 6). However, many additional specimens of intermediate colouration have since been found on Honshu and Shikoku, making the delimitation of these species unclear. Thus, it has been speculated that they all belong to a single species with a continuous gradient of colour variation.

Geographical colour variation across the Japanese Archipelago has been studied in various insects. For example, the elytral colour polymorphism of ladybirds shows that the frequency of dark forms is higher in high latitude areas (Kawakami et al., 2013). Similarly, there is a positive latitudinal gradient in the frequency of the black-mark morph of male pygmy grasshoppers Tetrix japonica (Bolívar) (Tsurui \& Nishida, 2010). Although some Japanese species of ichneumonids show marked geographical colour variation (Ito \& Maeto, 2014; Ito et al., 2014), there have been no quantitative analyses of the effect of geographical factors on the colour variation of the parasitoid wasps of the archipelago.

In this study, we first describe the genetic structure of the so-called "S. apicalis" and "S. tosensis" species by using DNA sequences of the mitochondrial COI and nuclear 28S rRNA genes. Second, to delimit the two species in question, we examine the morphological characteristics of adult wasps, in the context of the results of the DNA sequence 


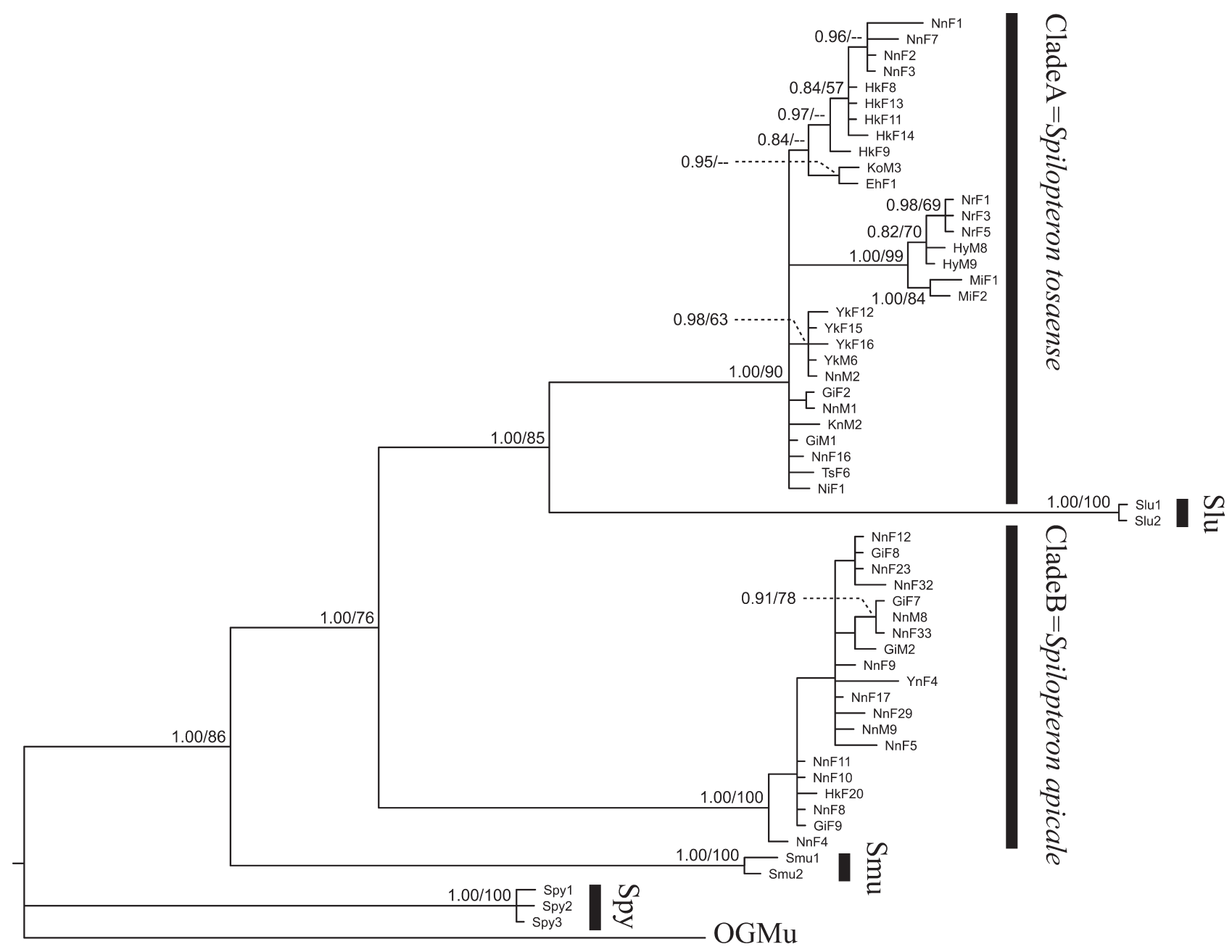

0.02

Fig. 1. BI tree of Spilopteron species based on mtCOI sequences. BI posterior probabilities $(>0.8)$ and ML bootstrap values $(>50 \%)$ are indicated at the nodes. Slu - S. luteum; Smu - S. mucronatum; Spy - S. pyrrhonae; OGMu - M. unicolor.

analyses, including type material of $S$. apicale and $S$. tosaense. Third, the intraspecific color variation is analyzed to determine whether it is influenced by any geographical factors.

\section{MATERIAL AND METHODS}

\section{Mitochondrial and nuclear DNA analyses}

We sequenced 52 Japanese individuals from the species complex (apicalis and tosensis), seven individuals of three other species of Spilopteron (luteum, mucronatum, pyrrhonae), and one individual of Metachorischizus unicolor Uchida as an outgroup species (Table S3).

A middle tarsus of each individual was removed and preserved in $99.5 \%$ ethanol. After drying, the tissue was ground in $20 \mu \mathrm{l}$ of $50 \mathrm{mM} \mathrm{NaOH}$ and digested for $15 \mathrm{~min}$ at $95^{\circ} \mathrm{C}$. After that, samples were neutralized using $20 \mu \mathrm{l}$ of $200 \mathrm{mM}$ Tris-HCl.

The mtCOI primers designed by Folmer et al. (1994) (LCO1490: 5' GGT CAA CAA ATC ATA AAG ATA TTG G3'; HCO2198: 5' TAA ACT TCA GGG TGA CCA AAA AAT CA3') (648 bp), and the nuclear 28S D2 primers designed by Campbell et al. (1993) (fwd: 5' AGT CGT GTT GCT TGA TAG TGC AG3'; rev: 5' TTG GTC CGT GTT TCA AGA CGG G3') (ca. $650 \mathrm{bp}$ ) were used for the polymerase chain reaction (PCR). PCR was conducted for COI and $28 \mathrm{~S}$ by using the KOD FX NEO kit (Toyobo), with an initial 2-min denaturation at $94^{\circ} \mathrm{C}$, followed by 35 cycles at $98^{\circ} \mathrm{C}$ for $10 \mathrm{~s}, 48^{\circ} \mathrm{C}$ for $30 \mathrm{~s}$, and $68^{\circ} \mathrm{C}$ for $15 \mathrm{~s}$. PCR products were purified using the illustra GFX kit (GE Healthcare Life Sciences). Gene regions were sequenced with the same primers used in the PCRs, and using the BigDye ${ }^{\mathrm{TM}}$ Terminator ver. 3.1 Cycle Sequencing kit (Applied Biosystems). The cycle sequencing programs both for COI and $28 \mathrm{~S}$ consisted of 25 cycles at $96^{\circ} \mathrm{C}$ for $10 \mathrm{~s}, 50^{\circ} \mathrm{C}$ for $5 \mathrm{~s}$, and $60^{\circ} \mathrm{C}$ for $4 \mathrm{~min}$. Cycle sequencing reactions were run on an ABI Prism 3100 Genetic Analyzer (Applied Biosystems).

For assembly and viewing of the sequence data, the DNA Dynamo Sequence Analyze Software program (Blue Tractor Software) was used. The sequences were aligned using ClustalW (http://www.genome.jp/tools/clustalw/). Bayesian inference (BI) analyses were performed for COI and $28 \mathrm{~S}$ using MrBayes ver. 3.2.3 (Ronquist et al., 2012). The model selection for BI was performed according to the Akaike information criterion (AIC) in MrModeltest 2.3 (Nylander, 2004). The best-fit substitution model was HKY, with rate heterogeneity among sites modeled using a proportion of invariable sites $(+\mathrm{I})$ and a gamma distribution $(+\mathrm{G})$ for the COI dataset and GTR $+\mathrm{G}$ for the $28 \mathrm{~S}$ dataset. Maximum likelihood (ML) trees were constructed for both COI and 28S using raxml GUI ver. 1.3.1 (Silvestro \& Michalak, 


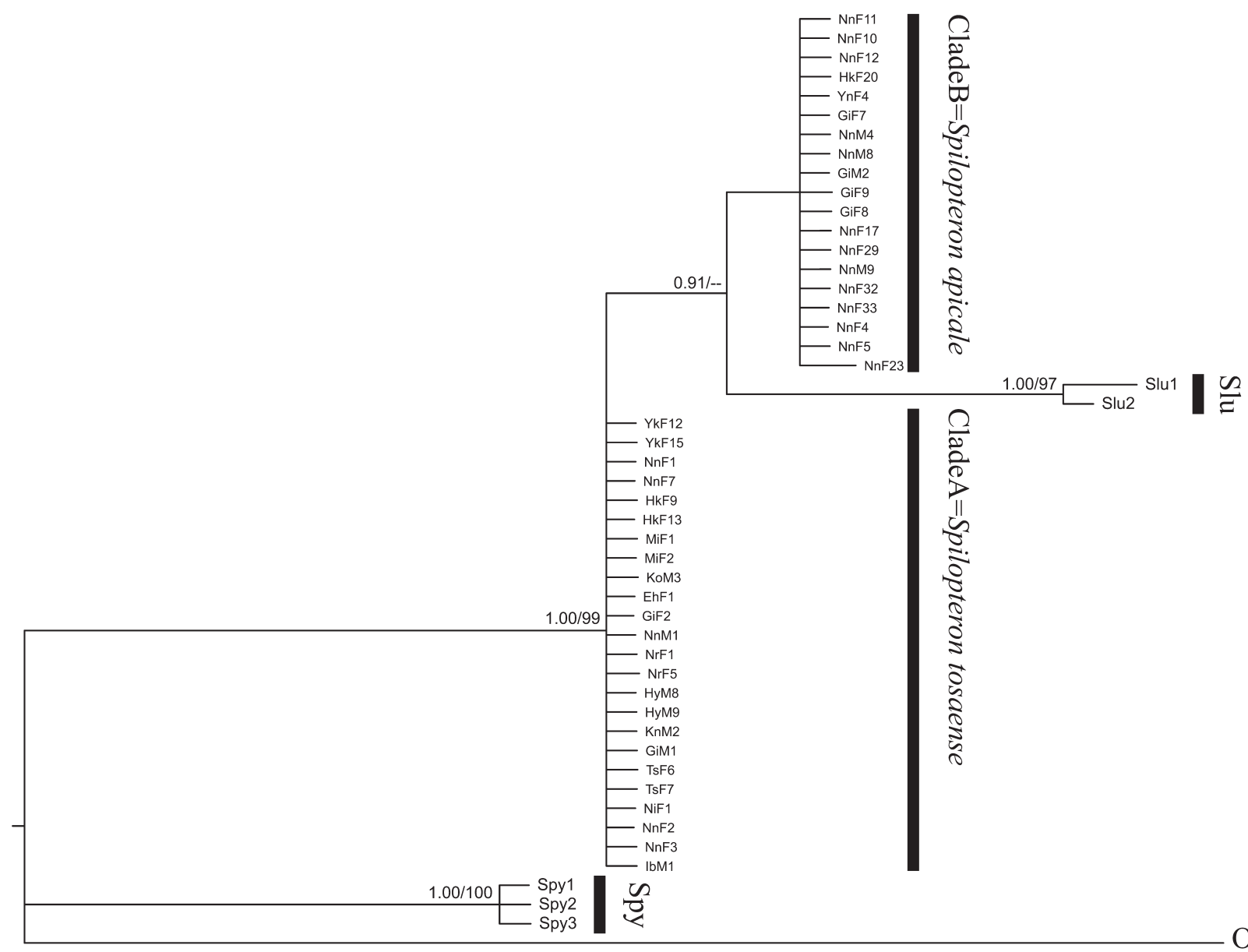

OGMu

0.002

Fig. 2. BI tree of Spilopteron species based on $28 \mathrm{~S}$ sequences. BI posterior probabilities $(>0.8)$ and ML bootstrap values $(>50 \%)$ are indicated at the nodes. Slu - S. luteum; Spy - S. pyrrhonae; OGMu - M. unicolor.

2012), and based on the GTR + G model, with 1000 bootstrap replications. Pairwise p-distances between individuals and clades were calculated using MEGA6.0 (Tamura et al., 2013). All the DNA sequences obtained were deposited in the DDBJ/EMBL GenBank database.

\section{Morphological examination}

We examined 345 dried adult specimens deposited in the following institutes: the Systematic Entomology, Hokkaido University, Sapporo (SEHU); the National Institute of Agro-Environmental Science, Tsukuba (NIAES); the National Museum of Nature and Science, Tsukuba (NSMT); the Kanagawa Prefectural Museum of Natural History, Odawara (KPMNH); the Entomological Laboratory of Meijo University, Nagoya (MU); the Osaka Museum of Natural History, Osaka (OMNH); the Ehime University, Matsuyama (EUM); and the Entomological Laboratory of Kagoshima University, Kagoshima (KU). The type series of $S$. apicale and $S$. tosaense (including the synonymous yakushimensis Uchida) deposited in SEHU were also examined.

Specimens were observed using a stereoscopic microscope (Nikon SMZ660). Photos (Figs 3, 6, 9) were taken using a digital camera (Nikon D60) or a digital microscope (Keyence Digital Microscope VHX-600). Scanning electron micrographs (Figs 4, 5) were taken using a JEOL JSM-6010LV SEM. General morphological terminology follows Gauld $(1991,2002)$ and terminology for surface sculpture follows Eady (1968).

\section{Geographical analysis of body colour variation in female S. tosaense}

Three body parts (face, mesopleuron and metasomal tergite $1)$ were coded as light (0) or dark (1), as shown in Fig. 8. The face was considered to be light (0) when it was entirely yellowish brown inside the rectangle below the antennal sockets or dark (1) when it was black, or at least partly so. The mesopleuron (excluding the dorsal region below the tegula) was light (0) when it was yellowish brown at least in part or dark (1) when it was entirely black. Tergite 1 was light (0) when the inside of the basal rectangle anterior of the spiracles was yellowish brown at least in part or dark (1) when it was entirely black. The effects of two geographical variables, altitude $(40-1570 \mathrm{~m})$ and latitude $\left(30-44^{\circ} \mathrm{N}\right)$, on the darkness indices were analyzed with Generalized Estimating Equations (GEE), using IBM SPSS Statistics for Windows, Version 19.0. The observed values ( 0 or 1$)$ of the darkness indices were specified to have a binomial distribution and a logit link function. The three body parts were treated as within-individual variables. After the analysis was performed using the data from 187 females, the overall predicted value (probability) of the darkness of each body part was calculated.

The observed darkness values and collection localities of the female specimens were positioned on the BI tree based on the mtCOI sequences, to show the geographical distribution of mitochondrial lineages and color forms within Japan. 

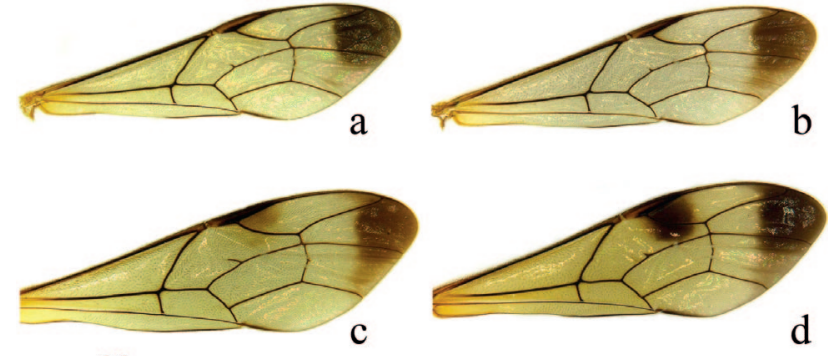

d

Fig. 3. Female fore wing. S. apicale (a) from Nagano Pref. and $S$. tosaense (b-d) from Hokkaido (b), Ishikawa Pref. (c), and Yakushima Is. (d).

\section{RESULTS}

\section{Molecular evidence}

Figs 1 and 2 show the BI trees based on the mitochondrial COI partial region (590 alignable bp) and the nuclear 28S D2 region (587 alignable bp), respectively, including the associated ML bootstrap values. The result of mtCOI analyses suggested the existence of two distinct clades, one of which contained specimens that could have been identified using existing characters as "S. apicalis" and " $S$. tosensis" (Clade A), and another which contained some " $S$. apicalis" specimens only (Clade B) (Fig. 1). The pair-wise p-distances within Clade A and Clade B were less than 0.037 and 0.017 , respectively, and the mean distance between them was 0.099 . Analyses of nuclear $28 \mathrm{~S}$ sequences also provided two groups corresponding to those obtained from the mtCOI analyses (Fig. 2). Both mtCOI and 28S analyses supported the monophyly of Clade A + Clade B $+S$. luteum; however, the relationships between them were not determined (Figs 1, 2).

\section{Morphological discrimination and taxonomy}

Clades A and B could be morphologically discriminated from each other. The apical dark mark on the fore wing was extended downwards in Clade A (Fig. 3b-d), while it was rounded and not extended downwards in Clade B (Fig. 3a). A depression between the eye and antennal socket on the frons was absent in Clade A (Fig. 4b), while it was present in Clade B (Fig. 4a). In addition, the apical margin of the
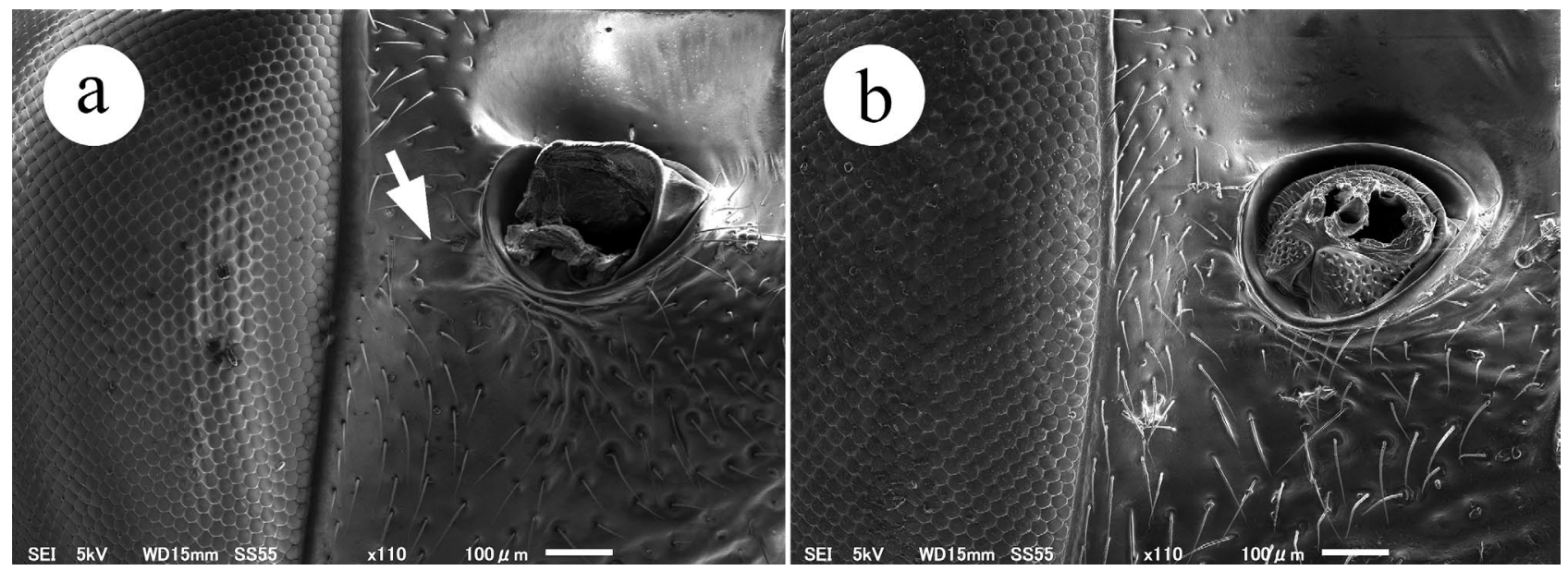

Fig. 4. Female frons. S. apicale (a) from Nagano Pref. and S. tosaense (b) from Yakushima Is. Arrow indicates a depression. clypeus had weak lateral projections in Clade A (Fig. 5b), while it had two strong lateral projections in Clade B (Fig. 5a). Based on the examination of type specimens of $S$. apibelongs to $S$. tosaense and Clade B to S. apicale (Fig. 6).

As our molecular data suggested, S. luteum from Japan and Taiwan was similar to $S$. apicale and S. tosaense. They could be distinguished from two other Japanese Spilopteron species, S. mucronatum and S. pyrrhonae, by the combination of the following character states: slenderness of the hind femur (without a ventral convexity), S1 with a round projection (without a sharp projection), and area superomedia confluent with area petiolaris. However, S. luteum was distinct from $S$. apicale and $S$. tosaense by the presence of a median longitudinal carina on the mesoscutum, a long lateral carina on the scutellum, and a strong lateral longitudinal carina on the propodeum (cf. Ito et al., 2012). The diagnosis, distribution, and other taxonomic information of $S$. apicale and $S$. tosaense is summarized below.

\section{Spilopteron apicale (Matsumura, 1912)}

Chorischizus apicalis Matsumura, 1912: 149. Spilopteron apicalis: Townes et al., 1965: 391. Spilopteron apicale: Yu et al., 2005, 2012.

Diagnosis. Fore wing with an apical dark mark rounded and not extended downward, without a dark mark below the pterostigma (Fig. 3a); frons with a depression between eye and antennal socket (Fig. 4a); clypeus with a very weak median projection and two strong lateral projections (Fig. 5a); body black; antennal flagellum with a white band; inner margin of eye, clypeus, basal area of mandible, subalar prominence, scutellum, postscutellum, apex of propodeum, front and middle legs, hind trochanter, hind trochantellus, apex of hind tarsus, and apices of T1 and T2 yellowish brown. Males same as females but face entirely yellow.

Distribution. Japan (Hokkaido, Honshu, Shikoku, and Kyushu) (Fig. 7a), and Far East Russia (Sakhalin). In central and southern Honshu, Shikoku and Kyushu occurring only at high altitudes (Fig. 8a). A record from China (Sheng et al., 2013) needs confirmation. cale and $S$. tosaense, it has been confirmed that Clade A 

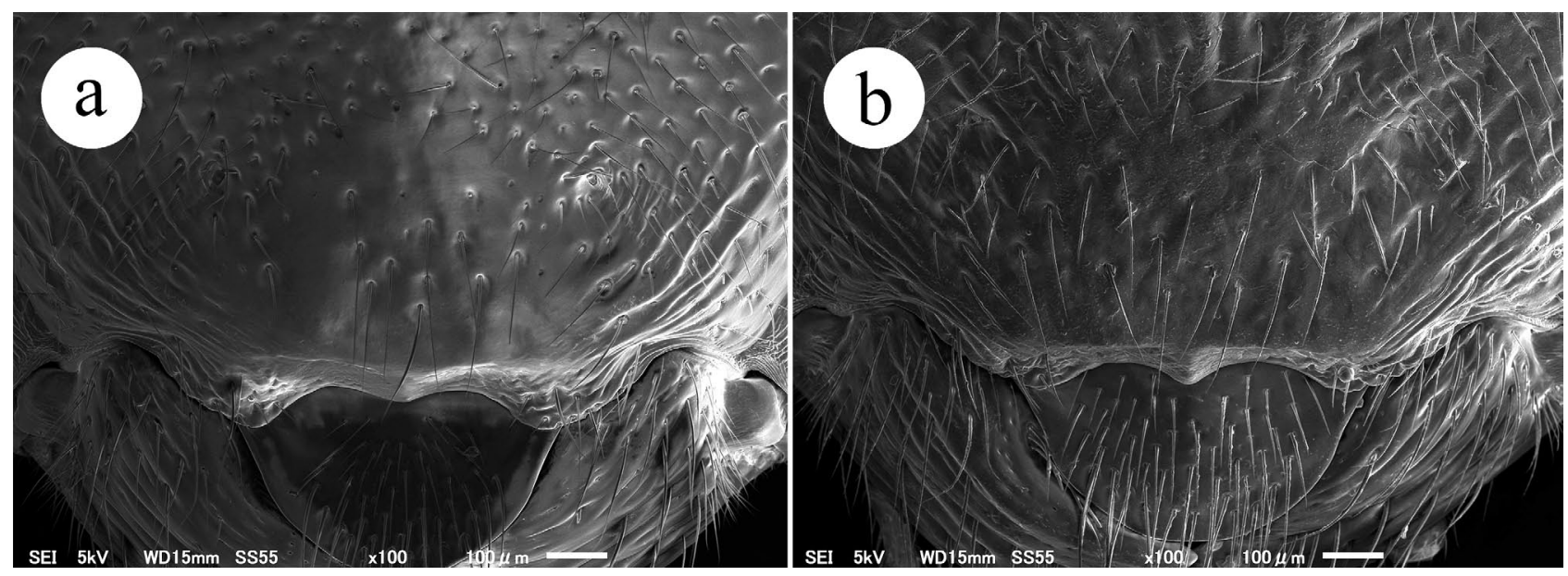

Fig. 5. Female clypeus. S. apicale (a) from Nagano Pref. and S. tosaense (b) from Yakushima Is.

Bionomics. Host unknown. Adults fly in July and August, visit flowers of Angelica spp. (Apiaceae), and oviposit on coniferous trunks in Japan (MI, pers. observ.).

Specimens examined. Lectotype: †, "Jyozan-kei, Sapporo City, Hokkaido, End of August 1907, S. Matsumura" (SEHU); paralectotype: + , "Sapporo City, Hokkaido, July 1907, S. Matsumura" (SEHU), both designated here. For additional specimens see Table S1.

\section{Spilopteron tosaense (Uchida, 1934)}

Siphimedia apicalis f. tosaensis Uchida, 1934: 53.

Siphimedia apicalis f. yakushimensis Uchida, 1934: 53. Synonymized by Townes et al. (1965).

Spilopteron tosensis: Townes et al., 1965: 391 (misspelling).

Spilopteron tosaense: Yu et al., 2005, 2012.

Diagnosis. Fore wing with an apical dark mark extended downward, sometimes with an additional dark mark below the pterostigma (Figs 3b-d); frons lacking a depression between eye and antennal socket (Fig. 4b); clypeus with a median and two lateral projections of equal size (Fig. 5b); body black to yellowish brown; antennal flagellum with a white band; inner margin of eye, clypeus, basal part of mandible, legs and basal part of metasomal tergite 1 yellowish brown to black; apical parts of metasomal tergites 1 and 2 yellowish brown (Fig. 9). Male same as female but body invariably yellow with dark stripes.

Distribution. Japan (Hokkaido*, Honshu, Sadogashima Is.*, Shikoku, Kyushu, Tsushima Is.*, and Yakushima Is.) (Figs 7b, $8 b) .(*$ - new record). A record from China (Sheng \& Sun, 2010) needs confirmation.

Bionomics. Host unknown. Adults fly in July and August, visit flowers of Angelica spp. (Apiaceae), and oviposit on coniferous trunks in Japan (MI, pers. observ.).

Specimens examined. Holotype of S. a. f. tosaensis: + , "Mt. Koeda, Prov. Tosa (Kochi Pref.), 12. July 1933, Y. Sugihara" (SEHU). Holotype of S. a. f. yakushimensis: ㅇ, "Hananoegawa, Kuriu, Yakushima Is. (Kagoshima Pref.), 31. July 1929, H. Hori” (SEHU). For additional specimens see Table S2.

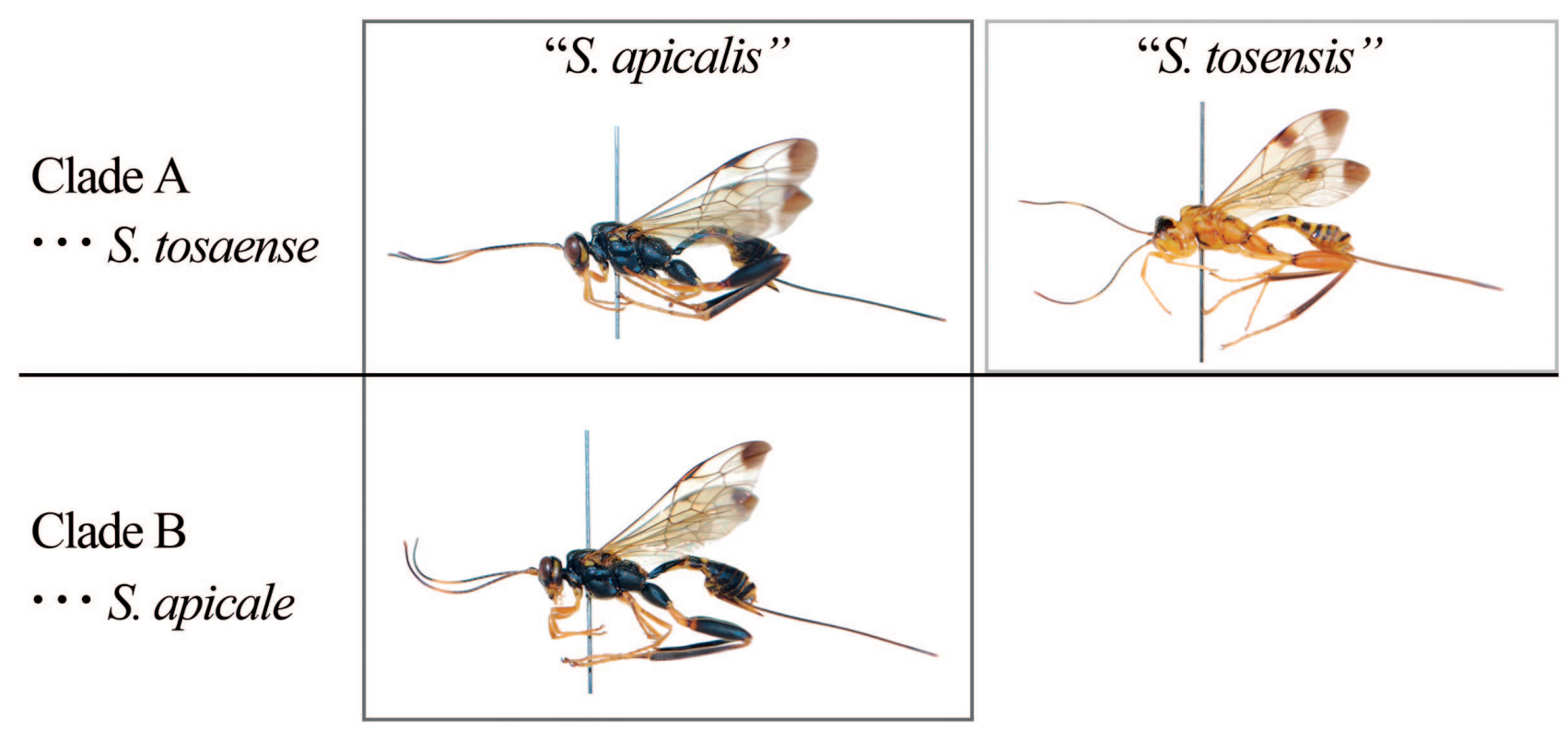

Fig. 6. Previous (in squares) and present classifications of S. apicale and S. tosaense. 


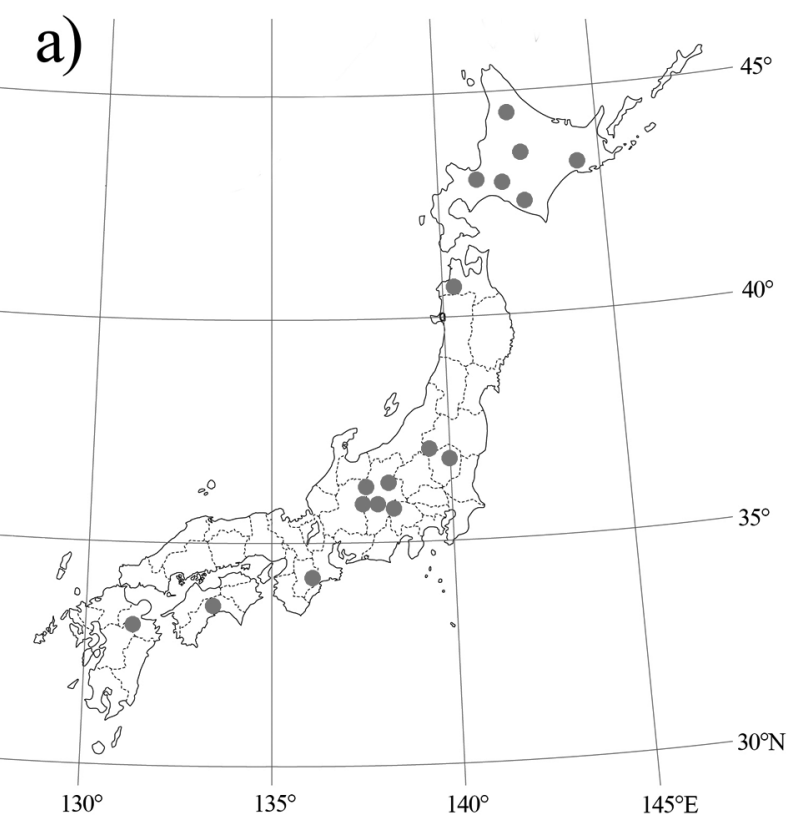

Fig. 7. Distribution of S. apicale (a) and S. tosaense (b) in Japan.

Remarks. The holotypes of S. a. f. tosaensis and S. a.f. yakushimensis differ in the colour of the mesosoma (mostly black in $S$. a. f. tosaensis but mostly yellowish brown in S. a. f. yakushimensis) and hind legs (dark brown in S. a. f. tosaensis but mostly yellowish brown in $S$. a. f. yakushimensis), but no other morphological differences were found between them. Therefore, we accept their synonymy proposed by Townes et al. (1965).

\section{A geographical gradient of color variation in S. tosaense}

The result of GEE showed that the effects of altitude and latitude on the body darkness of female $S$. tosaense were both significant and positive (Table 1). The darkness indices of all three body parts (Fig. 9) were predicted to increase with the degree of latitude, indicating a distinct gradient of body color variation along the latitudes of 30 $40^{\circ} \mathrm{N}$ (Fig. 10).

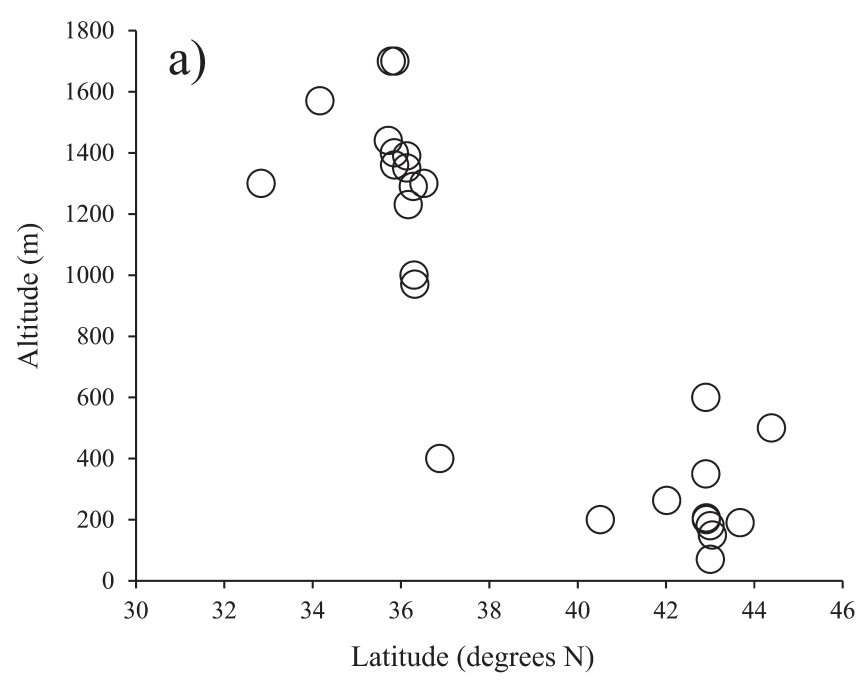

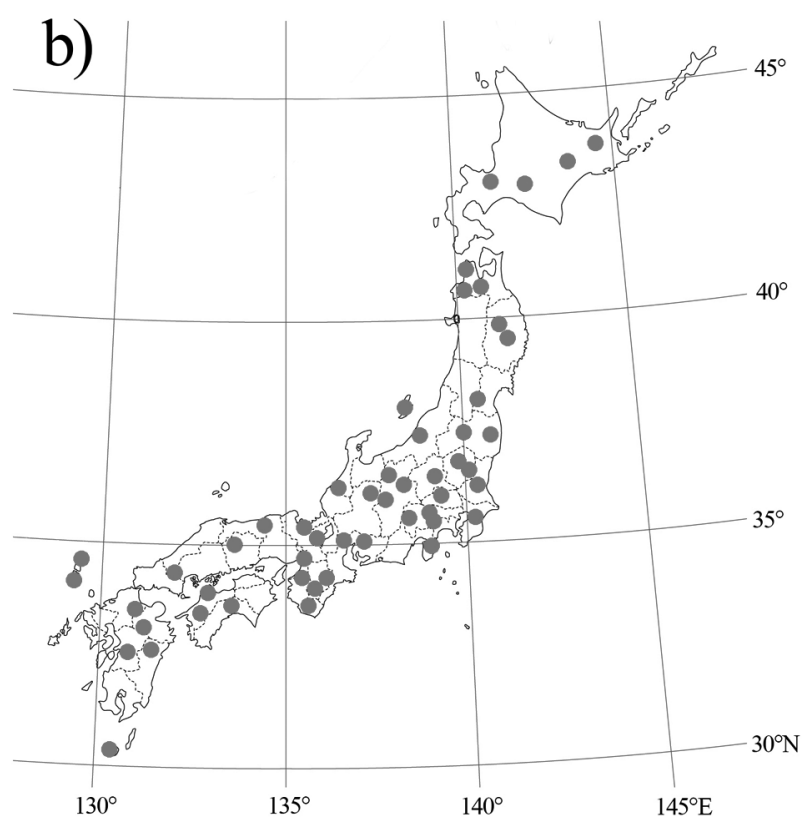

As shown in Fig. 11, there seems to be a mitochondrial lineage of dark specimens (1/1/1) (Fig. 9) distributed on Hokkaido and the highlands of Honshu and Shikoku, a lineage of light specimens $(0 / 0 / 0)$ (Fig. 9) on the southernmost island Yakushima, and a lineage of intermediate color forms $(0 / 1 / 1,1 / 1 / 0)$ on the Kii Peninsula of Honshu, but several other basal lineages of dark or light specimens were present in central Honshu and Tsushima Is.

\section{DISCUSSION}

Our molecular analyses and morphological examination have revealed that $S$. apicale is a monotypic, dark species found in northern or high altitude localities in Japan, while $S$. tosaense is a variously coloured species widely distributed from southern to northern Japan. Body color of female S. tosaense showed a marked geographical gradient, with individuals being increasingly dark with increasing latitude from Yakushima Is. to Hokkaido (Fig. 10).

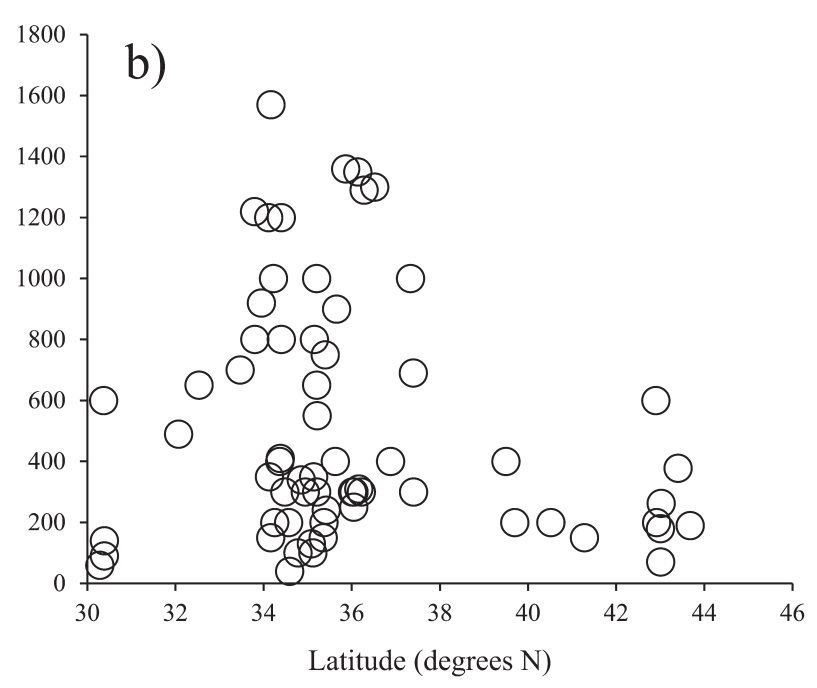

Fig. 8. Relationships of latitude and altitude in S. apicale (a) and S. tosaense (b). 


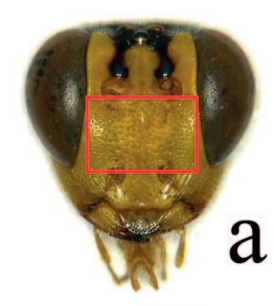

0
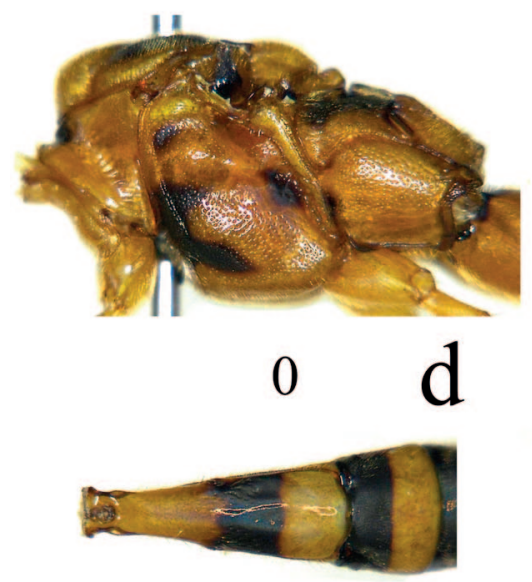

$\begin{array}{ll}0 & \mathrm{~g}\end{array}$
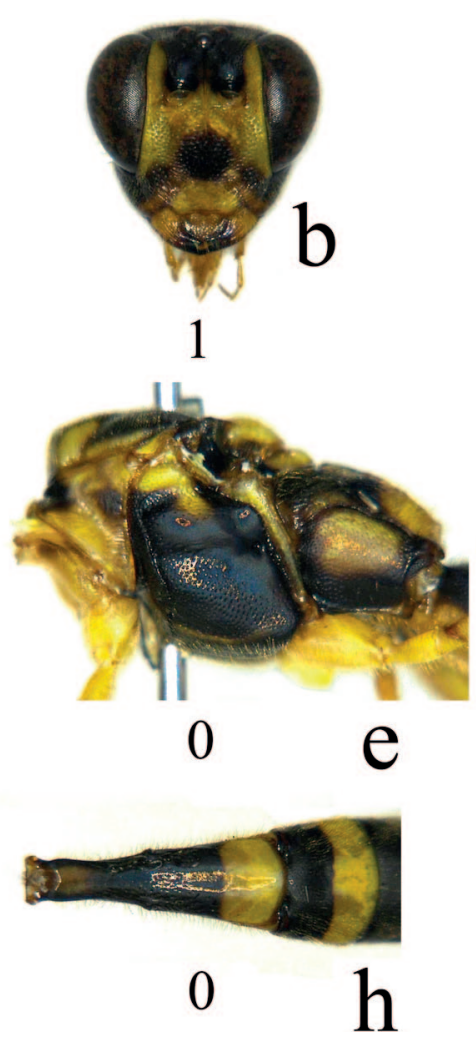
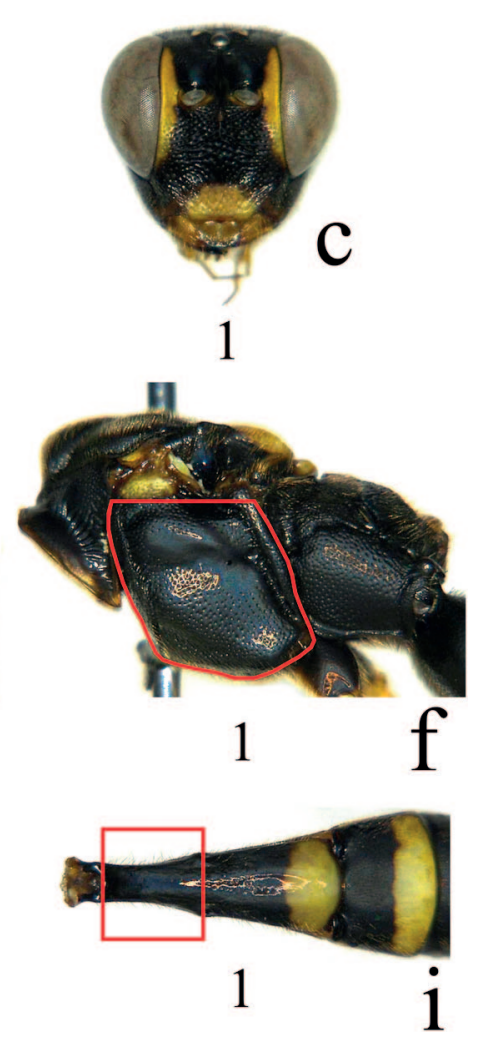

Fig. 9. Darkness indices $(0$ or 1$)$ of the face $(\mathrm{a}-\mathrm{c})$, mesopleuron $(\mathrm{d}-\mathrm{f})$, and metasomal tergite $1(\mathrm{~g}-\mathrm{i})$ of female $S$. tosaense from Hokkaido (c, f, i), Nara Pref. (b, h), Tsushima Is. (e), and Yakushima Is. (a, d, g). Red enclosures indicate the parts examined.

Within the Japanese Archipelago, some insects show a similar gradual increase in the frequency of dark forms with latitude (e.g., Tsurui \& Nishida, 2010; Kawakami et al., 2013). Such geographical gradients of insect body color are considered to be an adaptation to thermal conditions (Brakefield \& Willmer, 1985). The high frequencies of dark color morphs in the ladybird Adalia bipunctata (Linnaeus) associated with higher latitudes could be interpreted as being a thermal adaptation for absorbing more solar radiation. In contrast, the higher frequencies of light color morphs associated with a decrease in latitude may be an adaptation for reducing heat stress (Brakefield \& Willmer, 1985). In addition, the study on thermoregulatory function of a braconid parasitoid Meteorus pulchricornis (Wesmael) demonstrated that body color variation markedly affected the body temperature of adult wasps in sunlight (Abe et al., 2013).

One of other conceivable hypotheses is the different pathway of entry into Japan between two color forms of

TABLE 1. Result of a Generalized Estimating Equations (GEE) analysis on darkness indices.

\begin{tabular}{lcccc}
\hline Effect & Beta estimate & Wald Chi-Square & df & \multicolumn{1}{c}{ P } \\
\hline Intercept & -47.560 & 73.43 & 1 & $<0.001$ \\
Altitude (m) & 0.001 & 10.25 & 1 & 0.001 \\
Latitude (degrees N) & 1.340 & 72.21 & 1 & $<0.001$ \\
Part (face) & 1.065 & 15.46 & 1 & $<0.001$ \\
Part (mesopleuron) & 2.280 & 42.88 & 1 & $<0.001$ \\
Part (tergite 1) $^{\text {a }}$ & 0.000 & - & - & - \\
\hline
\end{tabular}

${ }^{a}$ Beta estimate is set to zero as a redundant parameter.
S. tosaense. According to this hypothesis, the dark-colored population may have entered northern Japan, while the light-colored population entered southern Japan separately, subsequently leading to the current latitudinal gradient of color variations. However, the results of the mitochondrial COI analyses seem to contradict this hypothesis, because the lineages of northern dark individuals and southern light individuals are not clearly defined. In fact, this indicates the occurrence of multiple introduction events, each establishing various color forms on the southern islands (Fig. 11).

Last but not least, it is also noteworthy that $S$. tosaense males lack any geographical color variation, and are always light colored. Female wasps must stay on tree trunks for long periods of time during oviposition, irrespective of the strength of solar radiation and the benefits provided by body color variation may be more significant for thermal regulation. Another possibility is that the color patterns of females are a form of camouflage or mimicry designed to avoid predation, most likely by birds, during oviposition. Such protection is not necessary for the males, which are free to escape predation by fleeing the predator. The body color patterns of certain groups of parasitoid wasps have been implicated in mimicry (Mason, 1964; Quicke et al., 1992), and predation pressure has the potential to limit the fitness of parasitoids in the field (Heimpel et al., 1997). Nevertheless, there is no available data that demonstrates the existence of a corresponding geographical gradient in camouflage backgrounds or mimicry models, and further research will be required to fully test this hypothesis. 
ACKNOWLEDGEMENTS. Our sincere thanks are due to K. Konishi (Ehime University), T. Yoshida (SEHU), R. Matsumoto $(\mathrm{OMNH})$, and S. Fujie (Osaka) for kindly offering materials, $\mathrm{K}$. Kusigemati, K. Tsuda, and Y. Sakamaki (KU), S. Yoshimatsu (NIAES), A. Shinohara (NSMT) and M. Ohara (SEHU) for their kind support in the investigation of their collections, M. Takeda and K. Sakamoto (Kobe University) for their kind permission to use their
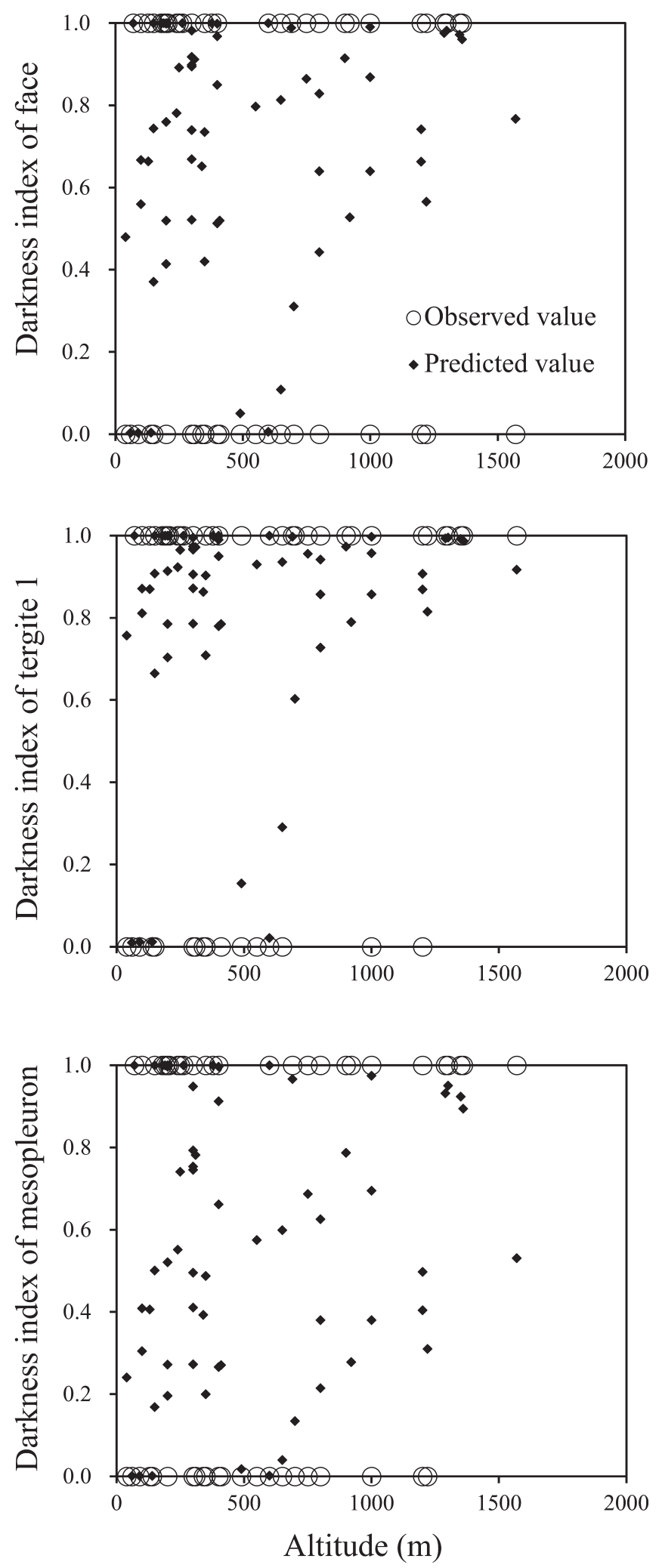

laboratory, K. Ikeda (Kobe University) for his kind permission to use his electron microscope, and R. Ogawa (Kobe University) for his kind instruction for using MrBayes and raxml GUI. This research was in part supported by the Sasakawa Scientific Research Grant from the Japan Science Society to MI and JSPS KAKENHI (Grant Number 25292034 to KM and 26840134 to KW).
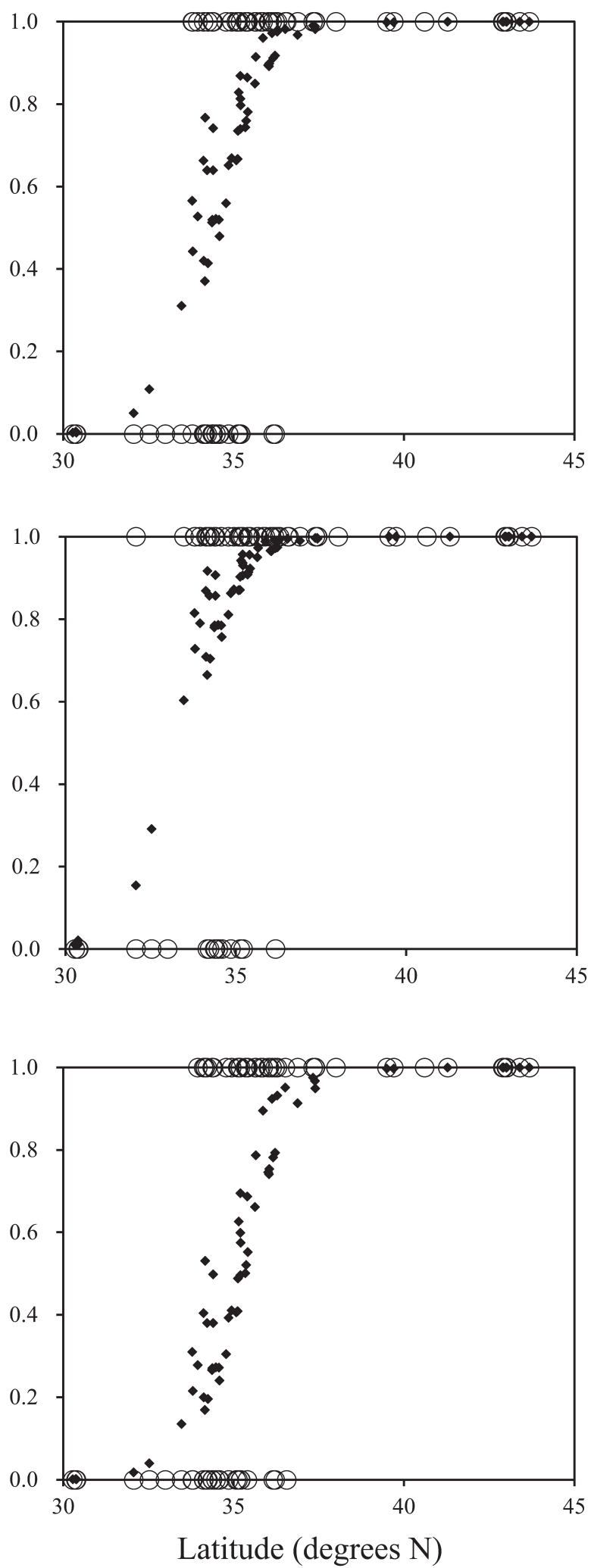

Fig. 10. Observed (0 or 1$)$ and GEE predicted values $(0-1)$ of the darkness indices on the three body parts (face, mesopleuron, and metasomal tergite 1) of female $S$. tosaense, in relation to altitude and latitude. 


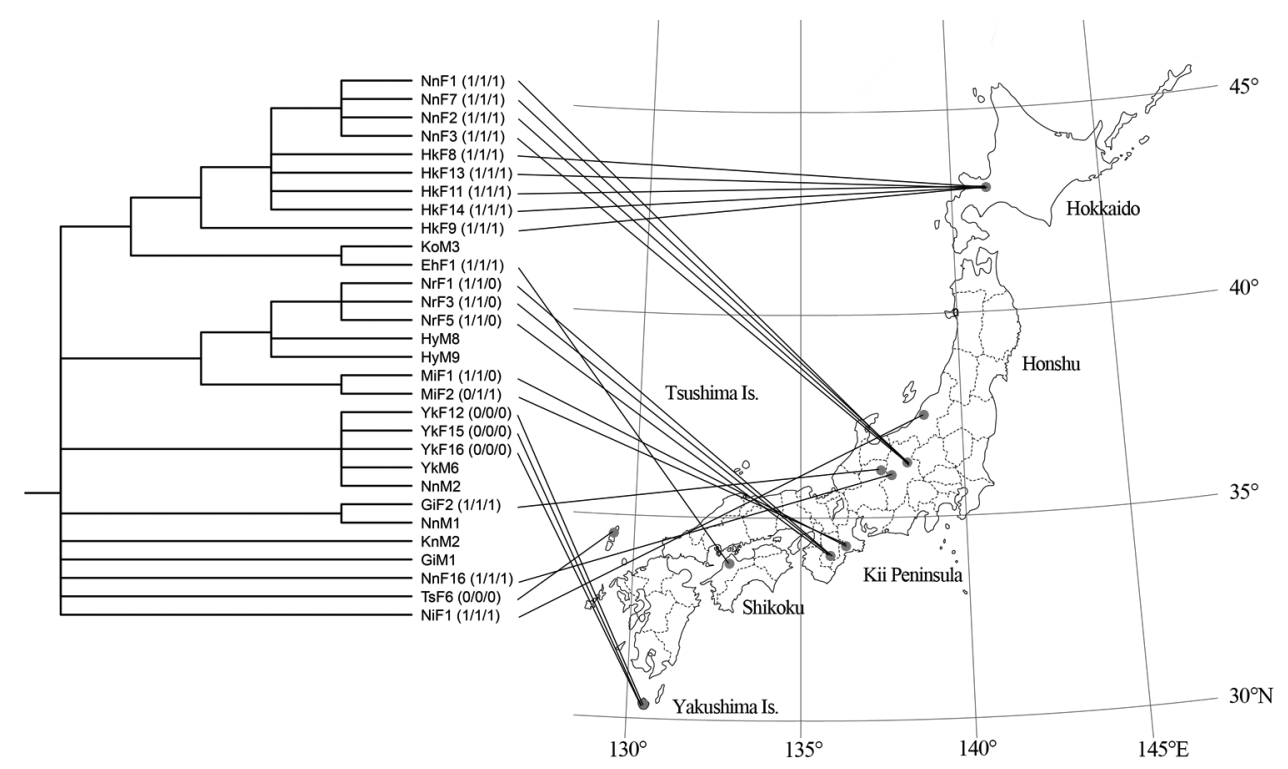

Fig. 11. Darkness indices (face/mesopleuron/metasomal tergite 1) and collection places of $S$. tosaense females positioned on the BI tree based on mtCOI (see Fig. 1).

\section{REFERENCES}

Abe Y., Nishimura T. \& Maeto K. 2013: Causes of polymorphic melanism and its thermoregulatory function in a parasitoid wasp Meteorus pulchricornis (Hymenoptera: Braconidae). Eur. J. Entomol. 110: 627-632.

Brakefield P.M. \& Willmer P.G. 1985: The basis of thermal melanism in the lady bird Adalia bipunctata: differences in reflectance and thermal properties between morphs. - Heredity 54: 9-14.

Campbell B.C., Steffen-Campbell J.D. \& Werren J.H. 1993 Phylogeny of the Nasonia species complex (Hymenoptera: Pteromalidae) inferred from an internal transcribed spacer (ITS2) and 28S rDNA sequences. - Insect Mol. Biol. 2: 225-237.

EADY R.D. 1968: Some illustrations of microsculpture in the Hymenoptera. - Proc. R. Entomol. Soc. Lond. 43(4-6): 66-72.

Folmer O., Black M., Hoeh W., Lutz R. \& Vrijenhoek R. 1994: DNA primers for amplification of mitochondrial cytochrome $\mathrm{c}$ oxidase subunit I from diverse metazoan invertebrates. - Mol. Marine Biol. Biotechnol. 3: 294-297.

GaUld I.D. 1991: The Ichneumonidae of Costa Rica, 1. - Mem. Am. Entomol. Inst. 47: 1-589.

GaUld I.D. 2002: The Ichneumonidae of Costa Rica, 4. - Mem. Am. Entomol. Inst. 66: 1-768.

Heimpel G.E., Rosenheim J.A. \& Mangel M. 1997: Predation on adult Aphytis parasitoids in the field. - Oecologia 110: 346 352.

Ito M. \& Maeto K. 2014: Revision of the genus Yamatarotes Uchida (Hymenoptera, Ichneumonidae, Acaenitinae) from Japan, based on morphological and molecular evidence. - Jap. J. Syst. Entomol. 20: 107-113.

Ito M., Watanabe K. \& Maeto K. 2012: Spilopteron luteum Uchida and S. mucronatus Lee (Hymenoptera, Ichneumonidae, Acaenitinae) new to Japan. - Jap. J. Syst. Entomol. 18: 443-446.

Ito M., Watanabe K. \& Maeto K. 2014: Revision of the genus Arotes Gravenhorst (Hymenoptera: Ichneumonidae: Acaenitinae) from Japan. - Zootaxa 3893: 196-208.

Kawakami Y., YamazaKi K. \& Ohashi K. 2013: Geographical variations of elytral color polymorphism in Cheilomenes sex- maculata (Fabricius) (Coleoptera: Coccinellidae). — Entomol. Sci. 16: 235-242.

Kusigemati K. 1981: Japanese species of the genus Spilopteron with description of a new species (Hymenoptera, Ichneumonidae). - Mem. Fac. Agr. Kagoshima Univ. 17: 117-125.

Mason W.R.M. 1964: Regional color patterns in the parasitic Hymenoptera. - Can. Entomol. 96: 132-134.

Matsumura S. 1912: Thousand Insects of Japan. Suppl. IV. Keishusha, Tokyo, $247 \mathrm{pp}$.

Nylander J.A.A. 2004: MrModeltest v2. Program distributed by the author, Evolutionary Biology Centre, Uppsala University.

Quicke D.L.J., Ingram S.N., Proctor J. \& Huddleston T. 1992: Batesian and Müllerian mimicry between species with connected life histories, with a new example involving braconid wasp parasites of Phoracantha beetles. - J. Nat. Hist. 26: 1013-1034.

Quicke D.L., Mori M., Zaldivar-Riveron A., Laurenne N.M. \& Shaw M.R. 2006: Suspended mummies in Aleiodes species (Hymenoptera: Braconidae: Rogadinae) with descriptions of six new species from western Uganda based largely on DNA sequence data. - J. Nat. Hist. 40: 2663-2680.

Ronquist F., Teslenko M., van der Mark P., Ayres D.L., Darling A., Höhna S., Larget B., Liu L., Suchard M.A. \& HuelsenBECK J.P. 2012: MrBayes 3.2: Efficient bayesian phylogenetic inference and model choice across a large model space. - Syst. Biol. 61: 539-542.

Rugman-Jones P.F., Wharton R., van Noort T. \& Stouthamer R. 2009: Molecular differentiation of the Psyttalia concolor (Szépligeti) species complex (Hymenoptera: Braconidae) associated with olive fly, Bactrocera oleae (Rossi) (Diptera: Tephritidae), in Africa and Pakistan. - Biol. Contr. 49: 17-26.

Shaw M.R. \& WAHL D.B. 1989: The biology, eggs and larvae of Acaenitus dubitator (Panzer) (Hymenoptera: Ichneumonidae: Acaenitinae). - Syst. Entomol. 14: 117-125.

Sheng M.L. \& Sun S.P. 2010: Parasitic Ichneumonids on Woodborers in China (Hymenoptera: Ichneumonidae). Science Press, Beijing, 338 pp. [in Chinese with English abstr.].

Sheng M.L., Sun S.P., Ding D.S. \& Luo J.G. 2013: Ichneumonid Fauna of Jiangxi (Hymenoptera: Ichneumonidae). Science Press, Beijing, 569 pp. [in Chinese with English abstr.]. 
Silvestro D. \& MichalaK I. 2012: raxmlGUi: a graphical frontend for RAxML. - Organisms Div. Evol. 12: 335-337.

Stigenberg J., Vikberg V. \& BelokobylskiJ S. 2011: Meteorus acerbiavorus sp. nov. (Hymenoptera, Braconidae), a gregarious parasitoid of Acerbia alpina (Quensel) (Lepidoptera, Arctiidae) in North Finland. - J. Nat. Hist. 45: 1275-1294.

Tamura K., Stecher G., Peterson D., Filipski A. \& Kumar S. 2013: MEGA6: Molecular evolutionary genetics analysis version 6.0. - Mol. Biol. Evol. 30: 2725-2729.

Townes H., Momoi S. \& Townes M. 1965: A catalogue and reclassification of the Eastern Palearctic Ichneumonidae. - Mem. Am. Entomol. Inst. 5: 1-661.

Tsurui K. \& Nishida T. 2010: Latitudinal clines of the blackmarking morph in a pygmy grasshopper Tetrix japonica (Orthoptera: Tetrigidae). — Bull. Osaka Mus. Nat. Hist. 64: 19-24 [in Japanese with English abstr.].
Tsurui K., Honma A. \& Nishida T. 2010: Camouflage effects of various colour-marking morphs against different microhabitat backgrounds in a polymorphic pygmy grasshopper Tetrix japonica. - PloS One 5(7): 1-7.

Uchida T. 1934: Beitrage zur Systematik der Tribus Acoenitini Japans (Hym. Ichneum. Pimplinae). - Insecta Matsum. 9: $41-54$.

Yu D.S., van Achterberg K. \& Horstmann K. 2005: World Ichneumonoidea 2004. Taxonomy, Biology, Morphology and Distribution. [CD-ROM]. Taxapad, Vancouver, Canada.

Yu D.S., van Achterberg K. \& Horstmann K. 2012: World Ichneumonoidea 2011. Taxonomy, Biology, Morphology and Distribution. [Flash drive]. Taxapad, Vancouver, Canada.

Received January 30, 2015; revised and accepted March 20, 2015 Prepublished online June 4, 2015

TABLE S1. Specimens of S. apicale used in the analysis.

\begin{tabular}{|c|c|c|c|c|c|c|c|c|c|}
\hline \multirow{2}{*}{ Locality } & & \multirow{2}{*}{ Collection date } & \multirow{2}{*}{ Code $^{1}$} & \multirow{2}{*}{ Alt. } & \multirow{2}{*}{ Lat. N } & \multirow{2}{*}{ Lon. E } & \multicolumn{2}{|c|}{ Accession number } & \multirow{2}{*}{ Depository } \\
\hline & & & & & & & & $28 \mathrm{~S}$ & \\
\hline \multirow[t]{24}{*}{ Hokkaido } & Sapporo City & 1-8. Aug., 2011 & HkF20 & 70 & 43.0 & 141.4 & LC041250 & LC041946 & OMNH \\
\hline & Sapporo City & 27. Jul.-21. Aug., 2007 & HkF31 & 600 & 42.9 & 141.9 & - & - & OMNH \\
\hline & Sapporo City & 4-27. Jul., 2007 & HkF32 & 600 & 42.9 & 141.9 & - & - & OMNH \\
\hline & Sapporo City & 27. Jul.-21. Aug., 2007 & HkF33 & 600 & 42.9 & 141.9 & - & - & EUM \\
\hline & Sapporo City & 27. Jul--21. Aug., 2007 & HkF34 & 600 & 42.9 & 141.9 & - & - & EUM \\
\hline & Sapporo City & 27. Jul--21. Aug., 2007 & HkF35 & 600 & 42.9 & 141.9 & - & - & EUM \\
\hline & Sapporo City & 27. Jul.-21. Aug., 2007 & HkF36 & 600 & 42.9 & 141.9 & - & - & EUM \\
\hline & Sapporo City & 27. Jul.-21. Aug., 2007 & HkF37 & 600 & 42.9 & 141.9 & - & - & EUM \\
\hline & Sapporo City & 27. Jul.-21. Aug., 2007 & HkF38 & 600 & 42.9 & 141.9 & - & - & EUM \\
\hline & Sapporo City & 27. Jul.-21. Aug., 2007 & HkF39 & 600 & 42.9 & 141.9 & - & - & EUM \\
\hline & Sapporo City & 24. Jul--24. Aug., 2006 & HkF28 & 206 & 42.9 & 141.9 & - & - & OMNH \\
\hline & Sapporo City & 24. Jul-24. Aug., 2006 & HkF29 & 206 & 42.9 & 141.9 & - & - & OMNH \\
\hline & Sapporo City & 3-17. Aug., 2007 & HkF24 & 180 & 43.0 & 142.1 & - & - & OMNH \\
\hline & Sapporo City & 24. Jul.-24. Aug., 2006 & HkF25 & 263 & 42.0 & 142.1 & - & - & OMNH \\
\hline & Sapporo City & 24. Jul.-24. Aug., 2006 & HkF26 & 263 & 42.0 & 142.1 & - & - & OMNH \\
\hline & Sapporo City & 19. Aug., 1966 & HkF47 & 150 & 43.0 & 141.3 & - & - & OMNH \\
\hline & Kuriyama Town & 16. Jul.-5. Aug., 2009 & HkF42 & 200 & 42.9 & 141.9 & - & - & OMNH \\
\hline & Teshikaga Town & 5. Aug., 2004 & HkF45 & 190 & 43.7 & 144.4 & - & - & OMNH \\
\hline & Sapporo City & 21-29. Jul., 1989 & HkF48 & 350 & 42.9 & 141.1 & - & - & NIAES \\
\hline & Horokanai Town & 9. Aug., 1981 & HkF40 & 500 & 44.4 & 142.3 & - & - & NIAES \\
\hline & Horokanai Town & 9. Aug., 1981 & HkF41 & 500 & 44.4 & 142.3 & - & - & NIAES \\
\hline & Mt. Petegariyama & 28 Jul., 1970 & HkF49 & - & 42.5 & 142.9 & - & - & NSMT \\
\hline & Samani Town & 8. Aug., 1970 & HkF50 & - & 42.1 & 143.0 & - & - & NSMT \\
\hline & Kushiro City & 6. Aug., 1947 & HkM1 & - & - & - & - & - & SEHU \\
\hline Aomori & Nishimeya Vill. & 6-14. Aug., 2013 & AoF6 & 200 & 40.5 & 140.2 & - & - & EUM \\
\hline \multirow{2}{*}{ Fukushima } & Hinoemata Vill. & 18. Aug., 1981 & $\mathrm{FsF} 3$ & - & 37.0 & 139.3 & - & - & NIAES \\
\hline & Hinoemata Vill. & 28-29. Jul., 1990 & FsF4 & - & 37.0 & 139.3 & - & - & NIAES \\
\hline Tochigi & Yaita City & 11-22. Aug., 1989 & TtF6 & 400 & 36.9 & 139.9 & - & - & NIAES \\
\hline \multirow{33}{*}{ Nagano } & Ueda City & 8. Aug.-3. Sep., 2014 & NnF4 & 1300 & 36.5 & 138.3 & LC041251 & LC041960 & KPMNH \\
\hline & Ueda City & 3. Sep--26. Sep., 2014 & NnF5 & 1300 & 36.5 & 138.3 & LC041252 & LC041961 & KPMNH \\
\hline & Nagawa Town & 25. Aug., 2011 & NnF8 & 1350 & 36.1 & 138.2 & LC041253 & - & OMNH \\
\hline & Nagawa Town & 25. Aug., 2011 & NnF9 & 1350 & 36.1 & 138.2 & LC041254 & - & OMNH \\
\hline & Nagawa Town & 25. Aug., 2011 & NnF10 & 1350 & 36.1 & 138.2 & LC041255 & LC041944 & OMNH \\
\hline & Nagawa Town & 22. Aug., 2012 & NnF11 & 1350 & 36.1 & 138.2 & LC041256 & LC041943 & OMNH \\
\hline & Nagawa Town & 23. Aug., 2012 & $\mathrm{NnF} 12$ & 1350 & 36.1 & 138.2 & LC041257 & LC041945 & OMNH \\
\hline & Nagawa Town & 22. Aug., 2012 & NnF13 & 1350 & 36.1 & 138.2 & - & - & OMNH \\
\hline & Nagawa Town & 26. Aug., 2011 & NnF14 & 1350 & 36.1 & 138.2 & - & - & OMNH \\
\hline & Nagawa Town & 27. Aug., 2011 & $\mathrm{NnF} 15$ & 1390 & 36.1 & 138.2 & - & - & OMNH \\
\hline & Outaki Vill. & 28. Jul., 2013 & NnF17 & 1360 & 35.9 & 137.6 & LC041258 & LC041955 & SEHU \\
\hline & Outaki Vill. & 31. Jul., 2013 & NnF18 & 1360 & 35.9 & 137.6 & - & - & KPMNH \\
\hline & Outaki Vill. & 31. Jul., 2013 & NnF19 & 1360 & 35.9 & 137.6 & - & - & KPMNH \\
\hline & Outaki Vill. & 31. Jul., 2013 & NnF20 & 1360 & 35.9 & 137.6 & - & - & KPMNH \\
\hline & Outaki Vill. & 31. Jul., 2013 & $\mathrm{NnF} 21$ & 1360 & 35.9 & 137.6 & - & - & KPMNH \\
\hline & Outaki Vill. & 31. Jul., 2013 & $\mathrm{NnF} 22$ & 1360 & 35.9 & 137.6 & - & - & KPMNH \\
\hline & Outaki Vill. & 28. Jul., 2013 & $\mathrm{NnF} 23$ & 1360 & 35.9 & 137.6 & LC041259 & - & SEHU \\
\hline & Outaki Vill. & 31. Jul., 2013 & NnF24 & 1360 & 35.9 & 137.6 & - & - & KPMNH \\
\hline & Outaki Vill. & 31. Jul., 2013 & $\mathrm{NnF} 25$ & 1360 & 35.9 & 137.6 & - & - & KPMNH \\
\hline & Outaki Vill. & 28. Jul., 2013 & NnF26 & 1700 & 35.9 & 137.5 & - & - & SEHU \\
\hline & Outaki Vill. & 28. Jul., 2013 & NnF27 & 1700 & 35.9 & 137.5 & - & - & SEHU \\
\hline & Outaki Vill. & 28. Jul., 2013 & NnF28 & 1700 & 35.9 & 137.5 & - & - & SEHU \\
\hline & Outaki Vill. & 28. Jul., 2013 & NnF29 & 1700 & 35.9 & 137.5 & LC041260 & LC041956 & SEHU \\
\hline & Outaki Vill. & 28. Jul., 2013 & NnF30 & 1700 & 35.9 & 137.5 & - & - & SEHU \\
\hline & Ina City & 30. Jul., 2013 & NnF31 & 1700 & 35.8 & 137.6 & - & - & KPMNH \\
\hline & Ina City & 30. Jul., 2013 & NnF32 & 1700 & 35.8 & 137.6 & LC041261 & LC041958 & KPMNH \\
\hline & Ina City & 30. Jul., 2013 & NnF33 & 1700 & 35.8 & 137.6 & LC041262 & LC041959 & KPMNH \\
\hline & Azumino City & 24. Aug., 2012 & NnF34 & 970 & 36.3 & 138.8 & - & - & OMNH \\
\hline & Karuizawa Town & 8. Sep., 1962 & NnF35 & 1000 & 36.3 & 138.5 & - & - & NSMT \\
\hline & Mt. Hakkaisan & 28. Jul., 2013 & NnM3 & - & - & - & - & - & SEHU \\
\hline & Mt. Hakkaisan & 28. Jul., 2013 & NnM4 & - & - & - & - & LC041949 & KPMNH \\
\hline & Mt. Hakkaisan & 6. Aug., 2007 & NnM5 & - & - & - & - & - & KPMNH \\
\hline & Mt. Hakkaisan & 7. Aug., 2010 & NnM6 & - & - & - & - & - & KPMNH \\
\hline
\end{tabular}




\begin{tabular}{|c|c|c|c|c|c|c|c|c|c|}
\hline \multirow{2}{*}{ Locality } & & \multirow{2}{*}{ Collection date } & \multirow{2}{*}{ Code $^{1}$} & \multirow{2}{*}{ Alt. } & \multirow{2}{*}{ Lat. N } & \multirow{2}{*}{ Lon. E } & \multicolumn{2}{|c|}{ Accession number } & \multirow{2}{*}{ Depository } \\
\hline & & & & & & & $\mathrm{COI}$ & $28 \mathrm{~S}$ & \\
\hline \multirow[t]{3}{*}{ Nagano } & Mt. Asamayama & 1. Aug., 1978 & NnM7 & - & - & - & - & - & OMNH \\
\hline & Ina City & 30. Jul., 2013 & NnM8 & 1300 & - & - & LC041264 & LC041950 & OMNH \\
\hline & Mt. Hakkaisan & 28. Jul., 2013 & NnM9 & - & - & - & LC041265 & LC041957 & $\mathrm{OMNH}$ \\
\hline \multirow{8}{*}{ Gifu } & Takayama City & 13. Aug., 2013 & GiF3 & 1290 & 36.3 & 137.6 & - & - & NSMT \\
\hline & Takayama City & 13. Aug., 2013 & GiF4 & 1290 & 36.3 & 137.6 & - & - & NSMT \\
\hline & Takayama City & 3. Aug., 2013 & GiF5 & 1290 & 36.3 & 137.6 & - & - & NIAES \\
\hline & Takayama City & 13. Aug., 2013 & GiF6 & 1290 & 36.3 & 137.6 & - & - & NSMT \\
\hline & Takayama City & 13. Aug., 2013 & GiF7 & 1290 & 36.3 & 137.6 & LC041266 & LC041948 & NSMT \\
\hline & Takayama City & 13. Aug., 2013 & GiF8 & 1290 & 36.3 & 137.6 & LC041267 & LC041953 & NSMT \\
\hline & Takayama City & 4. Aug., 2013 & GiF9 & 1230 & 36.2 & 137.5 & LC041268 & LC041952 & NIAES \\
\hline & Takayama City & 4. Aug., 2013 & GiM2 & - & 36.2 & - & LC041269 & LC041951 & NIAES \\
\hline \multirow[t]{10}{*}{ Yamanashi } & Hokuto City & 7. Aug., 2007 & YnF1 & 1400 & 35.9 & 138.6 & - & - & OMNH \\
\hline & Hokuto City & 8. Aug., 2008 & YnF2 & 1400 & 35.9 & 138.6 & - & - & OMNH \\
\hline & Hokuto City & 28. Jul.-7. Aug., 2007 & YnF3 & 1400 & 35.9 & 138.6 & - & - & $\mathrm{OMNH}$ \\
\hline & Hokuto City & 28. Jul.-7. Aug., 2007 & YnF4 & 1400 & 35.9 & 138.6 & LC041270 & LC041947 & $\mathrm{OMNH}$ \\
\hline & Hokuto City & 28. Jul.-7. Aug., 2007 & YnF5 & 1400 & 35.9 & 138.6 & - & - & $\mathrm{OMNH}$ \\
\hline & Hokuto City & 8. Aug., 2008 & YnF6 & 1400 & 35.9 & 138.6 & - & - & $\mathrm{OMNH}$ \\
\hline & Shioyama City & 5. Aug., 2008 & YnF7 & 1440 & 35.7 & 138.8 & - & - & KPMNH \\
\hline & Sagashino & 14. Aug., 1974 & YnF8 & - & - & - & - & - & NSMT \\
\hline & Owa Town & 5. Aug., 2008 & YnM4 & 900 & 35.7 & 138.8 & - & - & KPMNH \\
\hline & Akeno Vill. & 7. Aug., 2007 & YnM5 & - & - & - & - & - & KPMNH \\
\hline Nara & Kamikitayama Vill. & 15-22. Aug., 2005 & NrF9 & 1570 & 34.2 & 136.1 & - & - & OMNH \\
\hline Oita & Mt.Sobo-san & 28. Jul., 1978 & OiF2 & 1300 & 32.8 & 131.3 & - & - & NIAES \\
\hline
\end{tabular}

TABLE S2. Specimens of S. tosaense used in the analysis.

\begin{tabular}{|c|c|c|c|c|c|c|c|c|c|c|c|c|}
\hline \multirow[b]{2}{*}{ Locality } & & \multirow[b]{2}{*}{ Collection date } & \multirow[b]{2}{*}{ Code $^{1}$} & \multirow[b]{2}{*}{ Alt. } & \multirow[b]{2}{*}{ Lat. N } & \multirow[b]{2}{*}{ Lon. E } & \multicolumn{3}{|c|}{ Darkness index } & \multicolumn{2}{|c|}{ Accession number } & \multirow[b]{2}{*}{ Depository } \\
\hline & & & & & & & Face & $\begin{array}{c}\text { Meso- } \\
\text { pleuron }\end{array}$ & $\mathrm{T} 1$ & $\mathrm{COI}$ & $28 \mathrm{~S}$ & \\
\hline \multirow[t]{27}{*}{ Hokkaido } & Sapporo City & 25. Jul.-1. Aug., 2012 & HkF1 & 70 & 43.0 & 141.4 & 1 & 1 & 1 & - & - & EUM \\
\hline & Sapporo City & 25. Jul.-1. Aug., 2012 & HkF2 & 70 & 43.0 & 141.4 & 1 & 1 & 1 & - & - & EUM \\
\hline & Sapporo City & 25. Jul.-1. Aug., 2012 & HkF3 & 70 & 43.0 & 141.4 & 1 & 1 & 1 & - & - & EUM \\
\hline & Sapporo City & 25. Jul.-1. Aug., 2012 & HkF4 & 70 & 43.0 & 141.4 & 1 & 1 & 1 & - & - & EUM \\
\hline & Sapporo City & 4-11. Aug., 2008 & HkF5 & 70 & 43.0 & 141.4 & 1 & 1 & 1 & - & - & EUM \\
\hline & Sapporo City & 25. Jul--1. Aug., 2011 & HkF6 & 70 & 43.0 & 141.4 & 1 & 1 & 1 & - & - & EUM \\
\hline & Sapporo City & 25. Jul.-1. Aug., 2011 & HkF7 & 70 & 43.0 & 141.4 & 1 & 1 & 1 & - & - & EUM \\
\hline & Sapporo City & 26. Jul.-2. Aug., 2012 & HkF8 & 70 & 43.0 & 141.4 & 1 & 1 & 1 & LC041271 & - & EUM \\
\hline & Sapporo City & 20-27. Jul., 2010 & HkF9 & 70 & 43.0 & 141.4 & 1 & 1 & 1 & $\mathrm{LC} 041272$ & LC041962 & EUM \\
\hline & Sapporo City & 18-25. Jul., 2012 & HkF10 & 70 & 43.0 & 141.4 & 1 & 1 & 1 & - & - & EUM \\
\hline & Sapporo City & 4-11. Aug., 2008 & HkF11 & 70 & 43.0 & 141.4 & 1 & 1 & 1 & LC041273 & - & EUM \\
\hline & Sapporo City & 25. Jul.-1. Aug., 2011 & HkF12 & 70 & 43.0 & 141.4 & 1 & 1 & 1 & - & - & EUM \\
\hline & Sapporo City & 20-27. Jul., 2010 & HkF13 & 70 & 43.0 & 141.4 & 1 & 1 & 1 & LC041274 & LC041963 & EUM \\
\hline & Sapporo City & 1-8. Aug., 2011 & HkF14 & 70 & 43.0 & 141.4 & 1 & 1 & 1 & $\mathrm{LC} 041275$ & - & EUM \\
\hline & Sapporo City & 1-8. Aug., 2012 & HkF15 & 70 & 43.0 & 141.4 & 1 & 1 & 1 & - & - & EUM \\
\hline & Sapporo City & 1-8. Aug., 2012 & HkF16 & 70 & 43.0 & 141.4 & 1 & 1 & 1 & - & - & EUM \\
\hline & Sapporo City & 1-8. Aug., 2012 & HkF17 & 70 & 43.0 & 141.4 & 1 & 1 & 1 & - & - & EUM \\
\hline & Sapporo City & 1-8. Aug., 2011 & HkF18 & 70 & 43.0 & 141.4 & 1 & 1 & 1 & - & - & EUM \\
\hline & Sapporo City & 22-29. Aug., 2011 & HkF19 & 70 & 43.0 & 141.4 & 1 & 1 & 1 & - & - & EUM \\
\hline & Yubari City & 3-17. Aug., 2007 & HkF21 & 180 & 43.0 & 142.1 & 1 & 1 & 1 & - & - & OMNH \\
\hline & Yubari City & 24. Jul.-24. Aug., 2006 & $\mathrm{HkF} 22$ & 263 & 43.0 & 142.1 & 1 & 1 & 1 & - & - & OMNH \\
\hline & Yubari City & 24. Jul.-24. Aug., 2006 & $\mathrm{HkF} 23$ & 263 & 43.0 & 142.1 & 1 & 1 & 1 & - & - & OMNH \\
\hline & Kyriyama Town & 24. Jul-24. Aug., 2006 & $\mathrm{HkF} 27$ & 206 & 42.9 & 141.9 & 1 & 1 & 1 & - & - & OMNH \\
\hline & Ashoro Town & 17. Jul-7. Aug., 2008 & HkF46 & 378 & 43.4 & 143.9 & 1 & 1 & 1 & - & - & OMNH \\
\hline & Kyriyama Town & 16. Jul.-5. Aug., 2009 & $\mathrm{HkF} 43$ & 200 & 42.9 & 141.9 & 1 & 1 & 1 & - & - & OMNH \\
\hline & Sapporo City & 27. Jul.-21. Aug., 2007 & $\mathrm{HkF} 30$ & 600 & 42.9 & 141.9 & 1 & 1 & 1 & - & - & OMNH \\
\hline & Teshikaga Town & 5. Aug., 2004 & $\mathrm{HkF} 44$ & 190 & 43.7 & 144.4 & 1 & 1 & 1 & - & - & OMNH \\
\hline \multirow[t]{5}{*}{ Aomori } & Mt. Hakkodasan & 15. Aug., 1927 & AoF1 & & 40.6 & 140.8 & 1 & 1 & 1 & - & - & SEHU \\
\hline & Nakadomari Town & 28. Jul., 2013 & AoF2 & 150 & 41.3 & 140.3 & 1 & 1 & 1 & - & - & KPMNH \\
\hline & Nishimeya Vill. & 25. Jul.-6. Aug., 2013 & AoF3 & 200 & 40.5 & 140.2 & 1 & 1 & 1 & - & - & EUM \\
\hline & Nishimeya Vill. & 4-19. Aug., 2011 & AoF4 & 200 & 40.5 & 140.2 & 1 & 1 & 1 & - & - & EUM \\
\hline & Nishimeya Vill. & 4-19. Aug., 2011 & AoF5 & 200 & 40.5 & 140.2 & 1 & 1 & 1 & - & - & EUM \\
\hline \multirow[t]{2}{*}{ Iwate } & Shizukuishi Town & 9. Aug., 1975 & IwF1 & 200 & 39.7 & 141.0 & 1 & 1 & 1 & - & - & NIAES \\
\hline & Mt. Hayachinesan & 2-8. Aug., 1989 & IwF2 & 400 & 39.5 & 141.4 & 1 & 1 & 1 & - & - & NIAES \\
\hline Miyagi & Zao Town & 8. Aug., 1953 & MgF1 & & 38.0 & 140.4 & 1 & 1 & 1 & - & - & NIAES \\
\hline \multirow[t]{2}{*}{ Fukushima } & Mt. Hakaseyama & 29. Jun.-26. Jul., 1998 & FsF1 & 1000 & 37.3 & 139.7 & 1 & 1 & 1 & - & - & MU \\
\hline & Namie Town & em.19.Jun.1995 & FsF2 & 300 & 37.4 & 140.9 & 1 & 1 & 1 & - & - & NIAES \\
\hline \multirow[t]{6}{*}{ Tochigi } & Yaita City & 11-22. Aug., 1989 & $\mathrm{TtF} 1$ & 400 & 36.9 & 139.9 & 1 & 1 & 1 & - & - & NIAES \\
\hline & Yaita City & 11-22. Aug., 1989 & $\mathrm{TtF} 2$ & 400 & 36.9 & 139.9 & 1 & 1 & 1 & - & - & NIAES \\
\hline & Yaita City & 11-22. Aug., 1989 & $\mathrm{TtF} 3$ & 400 & 36.9 & 139.9 & 1 & 1 & 1 & - & - & NIAES \\
\hline & Yaita City & 11-22. Aug., 1989 & $\mathrm{TtF} 4$ & 400 & 36.9 & 139.9 & 1 & 1 & 1 & - & - & NIAES \\
\hline & Yaita City & 11-22. Aug., 1989 & TtF5 & 400 & 36.9 & 139.9 & 1 & 1 & 1 & - & - & NIAES \\
\hline & Mogi Town & 23. Jul., 2011 & TtM1 & - & - & - & - & - & - & - & - & KPMNH \\
\hline Gumma & Mt. Akagisan & 15-20. Aug., 1993 & $\mathrm{GuF} 1$ & & 36.6 & 139.2 & 1 & 1 & 0 & - & - & NSMT \\
\hline Ibaraki & Mt. Houkyousan & 28. Jun.-2. Aug., 2013 & $\mathrm{IbF} 1$ & 310 & 36.2 & 140.1 & 0 & 0 & 0 & - & - & NSMT \\
\hline & Tsuchiura City & 1. Jul., 2014 & IbM1 & 310 & 36.2 & 140.1 & - & - & - & - & LC041979 & NSMT \\
\hline Niigata & Mt. Nokogiriyama & 21. Jul.-21. Aug., 2014 & NiF1 & 690 & 37.4 & 138.9 & 1 & 1 & 1 & LC041276 & LC041976 & KPMNH \\
\hline Nagano & Ueda City & 10. Aug., 2012 & $\mathrm{NnF} 1$ & 1300 & 36.5 & 138.3 & 1 & 1 & 1 & LC041277 & LC041980 & KPMNH \\
\hline & Ueda City & 8. Aug.-3. Sep., 2014 & $\mathrm{NnF} 2$ & 1300 & 36.5 & 138.3 & 1 & 1 & 1 & LC041278 & LC041977 & KPMNH \\
\hline & Ueda City & 8. Aug.-3. Sep., 2014 & $\mathrm{NnF} 3$ & 1300 & 36.5 & 138.3 & 1 & 1 & 1 & LC041279 & LC041978 & KPMNH \\
\hline & Nagawa Town & 26. Aug., 2011 & NnF6 & 1350 & 36.1 & 138.2 & 1 & 1 & 1 & - & - & OMNH \\
\hline & Nagawa Town & 22. Aug., 2012 & NnF7 & 1350 & 36.1 & 138.2 & 1 & 1 & 1 & LC041280 & LC041981 & OMNH \\
\hline & Outaki Vill. & 31. Jul., 2013 & NnF16 & 1360 & 35.9 & 137.6 & 1 & 1 & 1 & LC041281 & - & NIAES \\
\hline & Outaki Vill. & 31. Jul., 2013 & NnM1 & 1360 & 35.9 & 137.6 & - & - & - & LC041282 & LC041969 & NIAES \\
\hline & Ueda City & 18. Aug., 2012 & $\mathrm{NnM} 2$ & 1300 & 36.5 & 138.3 & - & - & - & LC041283 & - & KPMNH \\
\hline
\end{tabular}




\begin{tabular}{|c|c|c|c|c|c|c|c|c|c|c|}
\hline & & & & & & & Darl & ness 1 & & Accessio \\
\hline Locality & & Collection date & Code $^{1}$ & Alt. & Lat. N & Lon. E & Face & & & $\mathrm{COI}$ \\
\hline Gifu & Takayama City & 13. Aug., 2013 & GiF1 & 1290 & 36.3 & 137.6 & 1 & 1 & 1 & - \\
\hline & Takayama City & 13. Aug., 2013 & GiF2 & 1290 & 36.3 & 137.6 & 1 & 1 & 1 & LC041284 \\
\hline & Takayama City & 4. Aug., 2013 & GiM1 & - & 36.3 & 137.5 & - & - & - & LC041285 \\
\hline Saitama & Ogawa Town & 12. Sep., 1992 & $\mathrm{SiF} 1$ & 300 & 36.0 & 139.2 & 1 & 1 & 1 & - \\
\hline & Ogawa Town & 23. Aug., 1992 & $\mathrm{SiF} 2$ & 300 & 36.0 & 139.2 & 1 & 1 & 1 & - \\
\hline & Ogawa Town & 23. Aug., 1992 & $\mathrm{SiF} 3$ & 300 & 36.0 & 139.2 & 1 & 1 & 1 & - \\
\hline & Yorii Town & 20. Jul., 1980 & $\mathrm{SiF} 4$ & 300 & 36.1 & 139.2 & 1 & 1 & 1 & - \\
\hline & Yorii Town & 25. Jul., 1980 & SiF5 & 300 & 36.1 & 139.2 & 1 & 1 & 1 & - \\
\hline & Otaki Vill. & 31. Jul., 1973 & SiF6 & & 35.8 & 138.9 & 1 & 1 & 1 & - \\
\hline & Mt. Sengenyama & 3. Aug., 1995 & SiF7 & 250 & 36.0 & 139.3 & 1 & 1 & 1 & - \\
\hline & Ootaki Town & 13-14. Jul., 2002 & SiM1 & - & - & - & - & - & - & - \\
\hline & Chichibu City & 20-21. Jul., 2013 & SiM2 & - & - & - & - & - & - & - \\
\hline & Higashichichibu Vill. & 20. Jul., 2013 & SiM3 & - & - & - & - & - & - & - \\
\hline & Higashichichibu Vill. & 20. Jul., 2013 & SiM4 & - & - & - & - & - & - & - \\
\hline Yamanashi & Koushu City & 5. Aug., 2008 & YnF9 & 900 & 35.7 & 138.8 & 1 & 1 & 1 & - \\
\hline & Maruno Town & 1. Aug.-10. Oct., 2007 & YnM1 & - & - & - & - & - & - & - \\
\hline & Maruno Town & 1. Aug. -10 . Oct., 2007 & YnM2 & - & - & - & - & - & - & - \\
\hline & Hokuto City & 8. Aug., 2008 & YnM3 & 1360 & 35.9 & 138.6 & - & - & - & - \\
\hline Гokyo & Mt. Takaosan & 21. Jul., 1968 & ToF1 & 400 & 35.6 & 139.2 & 1 & 1 & 1 & - \\
\hline & Mt. Takaosan & 10. Aug., 1964 & ToF2 & 400 & 35.6 & 139.2 & 1 & 1 & 1 & - \\
\hline Kanagawa & Mt. Koboyama & 28. Jun., 2008 & $\mathrm{KnF} 1$ & 200 & 35.4 & 139.3 & 1 & 1 & 1 & - \\
\hline & Odawara City & 11. Jul., 1987 & $\mathrm{KnF} 2$ & 300 & 35.2 & 139.1 & 1 & 1 & 1 & - \\
\hline & Odawara City & 16. Jul., 1987 & KnF3 & 300 & 35.2 & 139.1 & 1 & 1 & 1 & - \\
\hline & Odawara City & 25. Jul., 1987 & $\mathrm{KnF} 4$ & 300 & 35.2 & 139.1 & 1 & 1 & 1 & - \\
\hline & Hakone Town & 27. Jul., 1999 & KnM1 & - & - & - & - & - & - & - \\
\hline & Manaduru Town & 30. Jun., 2013 & KnM2 & 40 & 35.1 & 139.2 & - & - & - & LC041286 \\
\hline Chiba & Kimitsu City & 18. Jul., 2010 & TiM1 & - & - & - & - & - & - & - \\
\hline Shizuoka & Mishima City & 23. Jun.-8. Dec., 2012 & SzF1 & 100 & 35.1 & 138.9 & 1 & 1 & 1 & - \\
\hline & Higashiizu Town & 7. Jul., 2009 & SzF2 & 100 & 34.8 & 139.0 & 1 & 1 & 1 & - \\
\hline shikawa & Mt. Kariyasuyama & 28. Jun.-19. Jul., 2002 & IsF1 & 300 & 36.2 & 136.3 & 1 & 1 & 1 & - \\
\hline & Mt. Kariyasuyama & 28. Jun--18. Jul., 2002 & IsF2 & 300 & 36.2 & 136.3 & 1 & 1 & 1 & - \\
\hline & Mt. Kariyasuyama & 28. Jun. -19. Jul., 2002 & IsF3 & 300 & 36.2 & 136.3 & 1 & 1 & 0 & - \\
\hline & Mt. Kariyasuyama & 28. Jun.-19. Jul., 2002 & IsF4 & 300 & 36.2 & 136.3 & 1 & 1 & 1 & - \\
\hline & Mt. Kariyasuyama & 19-31. Jul., 2002 & IsF5 & 300 & 36.2 & 136.3 & 1 & 1 & 1 & - \\
\hline & Mt. Kariyasuyama & 28. Jun.-19. Jul., 2002 & IsF6 & 300 & 36.2 & 136.3 & 1 & 1 & 0 & - \\
\hline & Mt. Kariyasuyama & 28. Jun.-19. Jul., 2002 & IsF7 & 300 & 36.2 & 136.3 & 0 & 1 & 0 & - \\
\hline & Mt. Kariyasuyama & 19-31. Jul., 2002 & IsF8 & 300 & 36.2 & 136.3 & 1 & 1 & 0 & - \\
\hline & Mt. Kariyasuyama & 28. Jun.-19. Jul., 2002 & IsF9 & 300 & 36.2 & 136.3 & 1 & 1 & 0 & - \\
\hline & Mt. Kariyasuyama & 28. Jun.-19. Jul., 2002 & IsF10 & 300 & 36.2 & 136.3 & 1 & 1 & 0 & - \\
\hline & Mt. Kariyasuyama & 19-31. Jul., 2002 & IsF11 & 300 & 36.2 & 136.3 & 1 & 1 & 0 & - \\
\hline & Mt. Kariyasuyama & 18-30. Jul., 2002 & IsF12 & 300 & 36.2 & 136.3 & 1 & 1 & 0 & - \\
\hline & Mt. Kariyasuyama & 18-30. Jul., 2002 & IsF13 & 300 & 36.2 & 136.3 & 1 & 1 & 0 & - \\
\hline & Mt. Kariyasuyama & 19-31. Jul., 2002 & IsF14 & 300 & 36.2 & 136.3 & 1 & 1 & 1 & - \\
\hline & Mt. Kariyasuyama & 18-30. Jul., 2002 & IsF15 & 300 & 36.2 & 136.3 & 1 & 1 & 1 & - \\
\hline & Mt. Kariyasuyama & 28. Jun--19. Jul., 2002 & IsM1 & 300 & 36.2 & 136.3 & - & - & - & - \\
\hline Hyogo & Kami Town & 16. Jun.-14. Jul., 2013 & HyF1 & 750 & 35.4 & 134.5 & 1 & 1 & 1 & - \\
\hline & Kami Town & 16. Jun.-14. Jul., 2013 & HyF2 & 750 & 35.4 & 134.5 & 1 & 1 & 1 & - \\
\hline & Kami Town & 26. Jun.-18. Jul., 2011 & HyF3 & 750 & 35.4 & 134 & 1 & 1 & 1 & - \\
\hline & Kami Town & 16. Jun.-14. Jul., 2013 & HyF4 & 750 & 35.4 & 134.5 & 1 & 1 & 1 & - \\
\hline & Kami Town & 16. Jun--14. Jul., 2013 & HyF5 & 750 & 35.4 & 134.5 & 1 & 1 & 0 & - \\
\hline & Kami Town & 16. Jun.-14. Jul., 2013 & HyF6 & 750 & 35.4 & 134 & 1 & 1 & 0 & - \\
\hline & Kami Town & 16. Jun.-14. Jul., 2013 & HyF7 & 750 & 35.4 & 134.5 & 1 & 1 & 1 & - \\
\hline & Kami Town & 16. Jun.-14. Jul., 2013 & HyF8 & 750 & 35.4 & 134.5 & 1 & 1 & 1 & - \\
\hline & Kami Town & 16. Jun.-14. Jul., 2013 & HyF9 & 750 & 35.4 & 134.5 & 1 & 1 & 1 & - \\
\hline & Kami Town & 16. Jun.-14. Jul., 2013 & HyF10 & 750 & 35.4 & 134 & 1 & 1 & 1 & - \\
\hline & Kami Town & 16. Jun.-14. Jul., 2013 & HyF11 & 750 & 35.4 & 134.5 & 1 & 1 & 1 & - \\
\hline & Kami Town & 16. Jun.-14. Jul., 2013 & HyF12 & 750 & 35.4 & 134.5 & 1 & 1 & 1 & - \\
\hline & Kami Town & 16. Jun.-14. Jul., 2013 & HyF13 & 750 & 35.4 & 134.5 & 1 & 1 & 1 & - \\
\hline & Kami Town & 16. Jun.-14. Jul., 2013 & HyF14 & 750 & 35.4 & 134.5 & 1 & 1 & 0 & - \\
\hline & Haga Town & 4. Aug., 2003 & HyF15 & 550 & 35.2 & 134.5 & 0 & 0 & 0 & - \\
\hline & Kami Town & 16. Jun-14. Jul., 2013 & HyM1 & 750 & 35.4 & 134.5 & - & - & - & - \\
\hline & Kami Town & 16. Jun-14. Jul., 2013 & НyM2 & 750 & 35.4 & 134.5 & - & - & - & - \\
\hline & Kami Town & 16. Jun-14. Jul., 2013 & HyM3 & 750 & 35.4 & 134.5 & - & - & - & - \\
\hline & Kami Town & 16. Jun-14. Jul., 2013 & HyM4 & 750 & 35.4 & 134.5 & - & - & - & - \\
\hline & Kami Town & 16. Jun-14. Jul., 2013 & HyM5 & 750 & 35.4 & 134.5 & - & - & - & - \\
\hline & Kami Town & 16. Jun-14. Jul., 2013 & HyM6 & 750 & 35.4 & 134.5 & - & - & - & - \\
\hline & Kami Town & 16. Jun-14. Jul., 2013 & HyM7 & 750 & 35.4 & & - & - & - & - \\
\hline & Mt. Hyonosen & 13. Jul., 2013 & HyM8 & 500 & 35.3 & 134.6 & - & - & - & LC041287 \\
\hline & Mt. Hyonosen & 13. Jul., 2013 & НyM9 & 500 & & & - & - & - & LC041288 \\
\hline & Kami Town & 17. Jul., 2011 & HyM10 & 750 & 35.4 & 134.5 & - & - & - & - \\
\hline Kyoto & Kita Ward & 7. Aug., 2011 & $\mathrm{KyF} 1$ & 130 & 35.1 & 135.8 & 1 & 1 & 0 & - \\
\hline & Kyoto City & 30. Jul., 2008 & KyF2 & 800 & 35.2 & & 0 & 1 & 1 & - \\
\hline & Maizuru City & 1-15. Jul., 2008 & KyF3 & 240 & 35.4 & 134.3 & 1 & 1 & 1 & - \\
\hline & Hanase-toge & 22. Jul., 2004 & KyM1 & - & 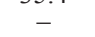 & . & - & - & - & - \\
\hline Shiga & Otsu City & 16. Aug., 2008 & $\mathrm{SgF} 1$ & 1000 & 35.2 & 135.9 & 1 & 1 & 0 & - \\
\hline & Otsu City & 29. Jul., 2008 & SgM1 & - & & & - & - & 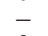 & - \\
\hline Aichi & Toyota City & 18-28. Jul., 1998 & AiF1 & 650 & 35.2 & 137.4 & 1 & 1 & 0 & - \\
\hline & Toyota City & 18-28. Jul., 1998 & $\mathrm{AiF} 2$ & 65 & 35.2 & 137.4 & 0 & 1 & 0 & - \\
\hline & Toyota City & 18-28. Jul., 1998 & AiF3 & 650 & 35.2 & 137.4 & 1 & 1 & 0 & - \\
\hline & Toyota City & 18-28. Jul., 1998 & AiF4 & 650 & 35.2 & 137.4 & 1 & 1 & 0 & - \\
\hline & Toyota City & 18-28. Jul., 1998 & AiF5 & - & - & - & 1 & 1 & 0 & - \\
\hline & Asuke Town & 28. Jun.-5. Jul., 2005 & AiM1 & - & - & - & - & - & - & - \\
\hline & Asuke Town & 28. Jun.-5. Jul., 2005 & AiM2 & - & - & - & - & - & - & - \\
\hline & Yawata Town & 17-26. Jun., 1998 & AiM3 & 650 & - & - & - & - & - & - \\
\hline & & 17-26. Jun., 1998 & & 650 & - & - & - & - & . & - \\
\hline & Yawata Town & 17-26. Jun., 1998 & AiM5 & 650 & - & - & - & - & - & - \\
\hline
\end{tabular}




\begin{tabular}{|c|c|c|c|c|c|c|c|c|c|}
\hline & & & & & & & Dar & kness inc & dex \\
\hline Locality & & Collection date & Code $^{1}$ & Alt. & Lat. $\mathrm{N}$ & Lon. E & Face & $\begin{array}{l}\text { Meso- } \\
\text { pleuron }\end{array}$ & \\
\hline Mie & Matsusaka City & 2. Sep., 2012 & MiF1 & 400 & 34.4 & 136.2 & 1 & 1 & 0 \\
\hline & Matsusaka City & 2. Sep., 2012 & MiF2 & 400 & 34.4 & 136.2 & 0 & 1 & 1 \\
\hline & Matsusaka City & 7. Aug., 2011 & $\mathrm{MiF} 3$ & 400 & 34.4 & 136.2 & 0 & 1 & 1 \\
\hline & Matsusaka City & 7. Aug., 2011 & MiF4 & 400 & 34.4 & 136.2 & 0 & 1 & 0 \\
\hline & Matsusaka City & 13. Aug., 2011 & MiF5 & 400 & 34.4 & 136.2 & 1 & 1 & 0 \\
\hline & Matsusaka City & 13. Aug., 2011 & MiF6 & 400 & 34.4 & 136.2 & 0 & 1 & 1 \\
\hline & Matsusaka City & 13. Aug., 2011 & MiF7 & 400 & 34.4 & 136.2 & 1 & 1 & 1 \\
\hline & Kuwana City & 12. Jul., 2009 & MiF8 & 350 & 35.1 & 136.6 & 0 & 1 & 0 \\
\hline & Kuwana City & 12. Jul., 2009 & MiF9 & 350 & 35.1 & 136.6 & 1 & 0 & 0 \\
\hline & Kuwana City & 12. Jul., 2009 & MiF10 & 350 & 35.1 & 136.6 & 1 & 1 & 0 \\
\hline & Kuwana City & 12. Jul., 2009 & MiF11 & 350 & 35.1 & 136.6 & 0 & 1 & 0 \\
\hline & Kuwana City & 12. Jul., 2009 & MiF12 & 350 & 35.1 & 136.6 & 0 & 1 & 0 \\
\hline & Kuwana City & 12. Jul., 2009 & MiF13 & 350 & 35.1 & 136.6 & 1 & 1 & 0 \\
\hline & Kuwana City & 12. Jul., 2009 & MiF14 & 350 & 35.1 & 136.6 & 1 & 1 & 0 \\
\hline & Kuwana City & 12. Jul., 2009 & MiF15 & 350 & 35.1 & 136.6 & 0 & 1 & 0 \\
\hline & Kuwana City & 12. Jul., 2009 & MiF16 & 350 & 35.1 & 136.6 & 1 & 1 & 0 \\
\hline & Kuwana City & 12. Jul., 2009 & MiF17 & 350 & 35.1 & 136.6 & 0 & 1 & 0 \\
\hline & Kuwana City & 12. Jul., 2009 & MiF18 & 350 & 35.1 & 136.6 & 1 & 1 & 0 \\
\hline & Kuwana City & 11. Jun., 2009 & MiF19 & 350 & 35.1 & 136.6 & 1 & 1 & 0 \\
\hline & Kuwana City & 11. Jun., 2009 & $\mathrm{MiF} 20$ & 350 & 35.1 & 136.6 & 1 & 1 & 0 \\
\hline & Kuwana City & 11. Jun., 2009 & MiF21 & 350 & 35.1 & 136.6 & 0 & 0 & 0 \\
\hline & Kuwana City & 11. Jun., 2009 & MiF22 & 350 & 35.1 & 136.6 & 1 & 1 & 1 \\
\hline & Kuwana City & 11. Jun., 2009 & $\mathrm{MiF} 23$ & 350 & 35.1 & 136.6 & 1 & 1 & 1 \\
\hline & Misugi Vill. & 24. Jul., 2011 & MiM1 & - & - & - & - & - & - \\
\hline & Misugi Vill. & 24. Jul., 2011 & MiM2 & - & - & - & - & - & - \\
\hline & Misugi Vill. & 24. Jul., 2011 & MiM3 & - & - & - & - & - & - \\
\hline & Misugi Vill. & 24. Jul., 2011 & MiM4 & - & - & - & - & - & - \\
\hline & Misugi Vill. & 24. Jul., 2011 & MiM5 & - & - & - & - & - & - \\
\hline & Misugi Vill. & 24. Jul., 2011 & MiM6 & - & - & - & - & - & - \\
\hline & Misugi Vill. & 24. Jul., 2011 & MiM7 & - & - & - & - & - & - \\
\hline & Misugi Vill. & 24. Jul., 2011 & MiM8 & - & - & - & - & - & - \\
\hline & Misugi Vill. & 24. Jul., 2011 & MiM9 & - & - & - & - & - & - \\
\hline Osaka & Kawachinagano City & 18. Jul., 2004 & OsF1 & 410 & 34.3 & 135.6 & 0 & 0 & 0 \\
\hline & Minoo City & 21. Jul.-16. Aug., 2006 & OsF2 & 340 & 34.9 & 135.5 & 0 & 0 & 0 \\
\hline & Takatsuki City & 30. Jun.-4. Aug., 2013 & OsF3 & 300 & 34.9 & 135.6 & 1 & 1 & 1 \\
\hline & Takatsuki City & 30. Jun-4. Aug., 2013 & OsF4 & 300 & 34.9 & 135.6 & 1 & 1 & 1 \\
\hline & Takatsuki City & 30. Jun. -4 . Aug., 2013 & OsF5 & 300 & 34.9 & 135.6 & 1 & 1 & 1 \\
\hline & Takatsuki City & 30. Jun.-4. Aug., 2013 & OsF6 & 300 & 34.9 & 135.6 & 1 & 1 & 1 \\
\hline & Takatsuki City & 30. Jun.-4. Aug., 2013 & OsF7 & 300 & 34.9 & 135.6 & 1 & 1 & 1 \\
\hline & Takatsuki City & 30. Jun.-4. Aug., 2013 & OsF8 & 300 & 34.9 & 135.6 & 1 & 1 & 1 \\
\hline & Takatsuki City & 30. Jun.-4. Aug., 2013 & OsF9 & 300 & 34.9 & 135.6 & 1 & 1 & 1 \\
\hline & Takatsuki City & 30. Jun.-4. Aug., 2013 & OsF10 & 300 & 34.9 & 135.6 & 1 & 1 & 1 \\
\hline & Takatsuki City & 30. Jun-4. Aug., 2013 & OsF11 & 300 & 34.9 & 135.6 & 1 & 1 & 1 \\
\hline & Kaizuka City & 20-30. Jun., 2003 & OsM1 & - & - & - & - & - & - \\
\hline Nara & Totsukawa Vill. & 10. Aug., 2013 & $\mathrm{NrF} 1$ & 1200 & 34.1 & 135.9 & 1 & 1 & 0 \\
\hline & Totsukawa Vill. & 20. Jul.-11. Aug., 2013 & $\mathrm{NrF} 2$ & 1200 & 34.1 & 135.9 & 1 & 1 & 0 \\
\hline & Totsukawa Vill. & 20. Jul.-11. Aug., 2013 & $\mathrm{NrF} 3$ & 1200 & 34.1 & 135.9 & 1 & 1 & 0 \\
\hline & Totsukawa Vill. & 20. Jul.-11. Aug., 2013 & $\mathrm{NrF} 4$ & 1200 & 34.1 & 135.9 & 0 & 1 & 1 \\
\hline & Totsukawa Vill. & 20. Jul.-11. Aug., 2013 & NrF5 & 1200 & 34.1 & 135.9 & 1 & 1 & 0 \\
\hline & Kamikitayama Vill. & 26. Jul., 2010 & NrF6 & 1000 & 34.2 & 136.0 & 0 & 1 & 0 \\
\hline & Kamikitayama Vill. & 15. Jul., 1999 & NrF7 & 1000 & 34.2 & 136.0 & 0 & 0 & 1 \\
\hline & Kamikitayama Vill. & 8-15. Aug., 2005 & NrF8 & 1570 & 34.2 & 136.1 & 0 & 1 & 1 \\
\hline & Mt. Azumidake & 6. Aug., 2010 & $\mathrm{NrF} 10$ & 150 & 35.4 & 135.1 & 1 & 1 & 1 \\
\hline & Mt. Azumidake & 6. Aug., 2010 & NrF11 & 150 & 35.4 & 135.1 & 1 & 1 & 1 \\
\hline Wakayama & Mt. Koyasan & 20. Jul., 1999 & WkM1 & - & - & - & - & - & - \\
\hline & Mt. Otousan & 13. Jun., 1999 & WkM2 & - & - & - & - & - & - \\
\hline & Mt. Hansarei & 14. Jun., 1999 & WkM3 & - & - & - & - & - & - \\
\hline & Mt. Hansarei & 14. Jun., 1999 & & - & - & - & - & - & - \\
\hline & Oishi-kogen & 15. Jul., 1994 & WkM5 & - & - & - & - & - & - \\
\hline Tottori & Mt. Hyonosen & 6. Aug., 2011 & ToM1 & 880 & 35.3 & 134.5 & - & - & - \\
\hline Hiroshima & Mt. Kakezuyama & 18. Jul., 1998 & HiM1 & - & - & - & - & - & - \\
\hline Ehime & Mt. Takanawasan & 11. Aug., 2013 & EhF1 & 920 & 33.9 & 132.9 & 1 & 1 & 1 \\
\hline & Oda Town & 17. Jul., 1995 & & - & - & - & 1 & 0 & 0 \\
\hline & Mt. Odamiyama & 16. Ju & EhM1 & - & - & - & - & - & - \\
\hline & Oda Town & 5. Jul., 1997 & EhM2 & - & - & - & - & - & - \\
\hline & Oda Town & 5. Jul., 1997 & EhM3 & - & - & - & - & - & - \\
\hline Kochi & Mt. Kanpuzan & 31. Jul., 2006 & KoF1 & 1220 & 33.8 & 133.3 & 1 & 1 & 0 \\
\hline & Mt. Kanpuzan & 31. Jul., 2006 & & 1220 & 33.8 & 133. & 1 & 1 & 0 \\
\hline & Mt. Kanpuzan & 31. Jul., 2006 & KoF3 & 1220 & 33.8 & 133.3 & 0 & 1 & 0 \\
\hline & Okawa Vill. & 21. Aug., 2000 & KoF4 & 800 & 33.8 & 133.4 & 1 & 1 & 0 \\
\hline & Mt. Kanpuzan & 31. Jul., 2006 & KoM1 & 1220 & 33.8 & 133.3 & - & - & - \\
\hline & Otoyo Town & 22-25. Jul., 2012 & Kol & - & - & - & - & - & - \\
\hline & Otoyo Town & $22-25$. Jul., 2012 & KoM3 & - & - & - & - & - & - \\
\hline Yamaguchi & Mt. Jakuchisan & 23. Aug., 1992 & YcF1 & 1200 & 34.4 & 132.0 & 0 & 0 & 1 \\
\hline & Mt. Jakuchisan & 21. Jun., 1999 & YcF2 & 800 & & & 1 & 1 & 1 \\
\hline Fukuoka & Mt. Hikosan & 28-29. Jul., 2007 & FoF1 & 700 & 33.5 & 130.9 & 0 & 1 & 0 \\
\hline Oita & Mt. Kujusan & 23. Jun., 1980 & OiF1 & - & 33.0 & 131.2 & 0 & 0 & 0 \\
\hline Kumamoto & Yatsu & & $\mathrm{KmF} 1$ & 650 & & & 0 & 0 & 0 \\
\hline & Yatsushiro City & 1. Aug., 1976 & $\mathrm{KmF} 2$ & 650 & 32.5 & 130.9 & 0 & 0 & 0 \\
\hline Nagasaki & Tsushima Is. & 12. Aug., 2001 & TsF1 & 350 & 34.1 & 129.2 & 0 & 1 & 0 \\
\hline & shima Is. & 25. Jul., 1994 & $\mathrm{TsF} 2$ & 200 & 34.3 & 129.2 & 1 & 1 & 0 \\
\hline & & 14. Aug., 1993 & TsF & 200 & 34.6 & 129.4 & 0 & 1 & 0 \\
\hline & Tsushima Is. & 7. Jul., 1984 & TsF4 & 300 & 34.5 & 129.4 & 0 & 0 & 0 \\
\hline & Tsushima Is. & 28. Aug., 1970 & TsF5 & 150 & 34.2 & 129.2 & 0 & 0 & 1 \\
\hline & Tsushima Is. & 5. Jul., 2014 & TsF6 & 40 & 34.6 & 129.4 & 0 & 0 & 0 \\
\hline & Tsushima Is. & 5. Jul., 2014 & TsF7 & 40 & 34.6 & 129.4 & 0 & 0 & 0 \\
\hline & Tsushima Is. & 14. Jul., 1992 & TsM1 & - & - & - & - & - & - \\
\hline
\end{tabular}


TABLE S2 (continued).

\begin{tabular}{|c|c|c|c|c|c|c|c|c|c|c|c|c|}
\hline \multirow[b]{2}{*}{ Locality } & & \multirow[b]{2}{*}{ Collection date } & \multirow[b]{2}{*}{ Code $^{1}$} & \multirow[b]{2}{*}{ Alt. } & \multirow[b]{2}{*}{ Lat. $\mathrm{N}$} & \multirow[b]{2}{*}{ Lon. E } & \multicolumn{3}{|c|}{ Darkness index } & \multicolumn{2}{|c|}{ Accession number } & \multirow[b]{2}{*}{ Depository } \\
\hline & & & & & & & & $\begin{array}{l}\text { Meso- } \\
\text { pleuron }\end{array}$ & $\mathrm{T} 1$ & COI & $28 \mathrm{~S}$ & \\
\hline \multirow[t]{3}{*}{ Miyazaki } & Kobayashi City & 16. Jul., 2004 & MzF1 & 490 & 32.1 & 131.0 & 0 & 0 & 0 & - & - & $\mathrm{OMNH}$ \\
\hline & Kobayashi City & 28. Jul., 2005 & MzF2 & 490 & 32.1 & 131.0 & 0 & 1 & 0 & - & - & $\mathrm{OMNH}$ \\
\hline & Kitagata Town & 21. Jul., 2008 & MzM1 & 1000 & - & - & - & - & - & - & - & OMNH \\
\hline \multirow[t]{30}{*}{ Kagoshima } & Yakushima Is. & 14. Jul., 1994 & YkF1 & 60 & 30.3 & 130.4 & 0 & 0 & 0 & - & - & $\mathrm{OMNH}$ \\
\hline & Yakushima Is. & 9. Aug.-2. Sep., 2000 & YkF2 & 600 & 30.4 & 130.6 & 0 & 0 & 0 & - & - & MU \\
\hline & Yakushima Is. & 28. Jun., 2012 & $\mathrm{YkF} 3$ & 90 & 30.4 & 130.6 & 0 & 0 & 0 & - & - & KPMNH \\
\hline & Yakushima Is. & 3. Jul., 2012 & YkF4 & 90 & 30.4 & 130.6 & 0 & 0 & 0 & - & - & $\mathrm{OMNH}$ \\
\hline & Yakushima Is. & 28. Jun., 2012 & YkF5 & 90 & 30.4 & 130.6 & 0 & 0 & 0 & - & - & KPMNH \\
\hline & Yakushima Is. & 28. Jun., 2012 & YkF6 & 90 & 30.4 & 130.6 & 0 & 0 & 0 & - & - & KPMNH \\
\hline & Yakushima Is. & 3. Jul., 2012 & YkF7 & 90 & 30.4 & 130.6 & 0 & 0 & 0 & - & - & OMNH \\
\hline & Yakushima Is. & 28. Jun., 2012 & YkF8 & 90 & 30.4 & 130.6 & 0 & 0 & 0 & - & - & KPMNH \\
\hline & Yakushima Is. & 28. Jun., 2012 & YkF9 & 90 & 30.4 & 130.6 & 0 & 0 & 0 & - & - & KPMNH \\
\hline & Yakushima Is. & 28. Jun., 2012 & YkF10 & 90 & 30.4 & 130.6 & 0 & 0 & 0 & - & - & KPMNH \\
\hline & Yakushima Is. & 28. Jun., 2012 & YkF11 & 90 & 30.4 & 130.6 & 0 & 0 & 0 & - & - & KPMNH \\
\hline & Yakushima Is. & 28. Jun., 2012 & YkF12 & 90 & 30.4 & 130.6 & 0 & 0 & 0 & LC041297 & LC041982 & KPMNH \\
\hline & Yakushima Is. & 29. Jun., 2012 & YkF13 & 90 & 30.4 & 130.6 & 0 & 0 & 0 & - & - & SEHU \\
\hline & Yakushima Is. & 3. Jul., 2012 & YkF14 & 90 & 30.4 & 130.6 & 0 & 0 & 0 & - & - & OMNH \\
\hline & Yakushima Is. & 29. Jun., 2012 & YkF15 & 140 & 30.4 & 130.4 & 0 & 0 & 0 & LC041298 & LC041983 & SEHU \\
\hline & Yakushima Is. & 29. Jun., 2012 & YkF16 & 140 & 30.4 & 130.4 & 0 & 0 & 0 & LC041299 & - & SEHU \\
\hline & Yakushima Is. & 28. Jun., 2012 & YkF17 & 140 & 30.4 & 130.4 & 0 & 0 & 0 & - & - & KPMNH \\
\hline & Yakushima Is. & 2. Jul., 2012 & YkF18 & 140 & 30.4 & 130.4 & 0 & 0 & 0 & - & - & OMNH \\
\hline & Yakushima Is. & 2. Jul., 2012 & YkF19 & 140 & 30.4 & 130.4 & 0 & 0 & 0 & - & - & OMNH \\
\hline & Yakushima Is. & 29. Jun., 2012 & YkF20 & 140 & 30.4 & 130.4 & 0 & 0 & 0 & - & - & SEHU \\
\hline & Yakushima Is. & 29. Jun., 2012 & YkF21 & 140 & 30.4 & 130.4 & 0 & 0 & 0 & - & - & SEHU \\
\hline & Yakushima Is. & 29. Jun., 2012 & YkF22 & 140 & 30.4 & 130.4 & 0 & 0 & 0 & - & - & SEHU \\
\hline & Yakushima Is. & 8. Jul., 2010 & YkM1 & - & - & - & - & - & - & - & - & KPMNH \\
\hline & Yakushima Is. & 21. Jun.-9. Jul., 2000 & YkM2 & 600 & - & - & - & - & - & - & - & MU \\
\hline & Yakushima Is. & 21. Jun.-9. Jul., 2000 & YkM3 & 600 & - & - & - & - & - & - & - & MU \\
\hline & Yakushima Is. & 21. Jun., 2012 & YkM4 & - & - & - & - & - & - & - & - & KPMNH \\
\hline & Yakushima Is. & 2. Jul., 2012 & YkM5 & 140 & 30.4 & 130.4 & - & - & - & - & - & KPMNH \\
\hline & Yakushima Is. & 29. Jun., 2012 & YkM6 & 140 & 30.4 & 130.4 & - & - & - & LC041300 & - & KPMNH \\
\hline & Yakushima Is. & 29. Jun., 2012 & YkM7 & 140 & 30.4 & 130.4 & - & - & - & - & - & KPMNH \\
\hline & Yakushima Is. & 29. Jun., 2012 & YkM8 & 140 & 30.4 & 130.4 & - & - & - & - & - & KPMNH \\
\hline
\end{tabular}

TABLE S3. Specimens of out-groups used in the analysis.

\begin{tabular}{|c|c|c|c|c|c|c|c|}
\hline \multirow{2}{*}{ Species } & \multirow{2}{*}{ Locality } & \multirow{2}{*}{ Collection date } & \multirow{2}{*}{ Sex } & \multirow{2}{*}{ Code } & \multicolumn{2}{|c|}{ Accession number } & \multirow{2}{*}{ Depository } \\
\hline & & & & & $\mathrm{COI}$ & $28 \mathrm{~S}$ & \\
\hline M. unicolor & Yakushima Is. & 2. Jul., 2012 & Male & $\mathrm{OgMu}$ & LC008221 & LC041991 & NSMT \\
\hline S. pyrrhonae & Shizuoka Pref. & 27. Apr., 2013 & Male & Spy1 & LC041305 & LC041988 & OMNH \\
\hline S. pyrrhonae & Shizuoka Pref. & 27. Apr., 2013 & Male & Spy2 & LC041306 & LC041989 & OMNH \\
\hline S. pyrrhonae & Shizuoka Pref. & 27. Apr., 2013 & Female & Spy3 & LC041307 & LC041990 & NIAES \\
\hline S. luteum & Amami-oshima Is. & 27. Jun., 2011 & Male & Slu1 & LC041303 & LC041986 & $\mathrm{OMNH}$ \\
\hline S. luteum & Amami-oshima Is. & 28. Jun., 2011 & Female & Slu2 & LC041304 & LC041987 & $\mathrm{OMNH}$ \\
\hline S. mucronatum & Kyoto Pref. & 23. Jun., 2012 & Female & Smu1 & LC041301 & - & NIAES \\
\hline S. mucronatum & Hokkaido & 13. Jul., 2012 & Male & Smu2 & LC041302 & - & NIAES \\
\hline
\end{tabular}

